Pace University

DigitalCommons@Pace

$1-1-2008$

\title{
Returning to Hazelwood's Core: A New Approach to Restrictions on School-Sponsored Speech
}

\author{
Emily Gold Waldman \\ Elisabeth Haub School of Law at Pace University
}

Follow this and additional works at: https://digitalcommons.pace.edu/lawfaculty

Part of the Constitutional Law Commons, and the Education Law Commons

\section{Recommended Citation}

Emily Gold Waldman, Returning to Hazelwood's Core: A New Approach to Restrictions on SchoolSponsored Speech, 60 Fla. L. Rev. 63 (2008), http://digitalcommons.pace.edu/lawfaculty/286/.

This Article is brought to you for free and open access by the School of Law at DigitalCommons@Pace. It has been accepted for inclusion in Pace Law Faculty Publications by an authorized administrator of DigitalCommons@Pace. For more information, please contact dheller2@law.pace.edu. 


\section{Returning to Hazelwood's Core: A New Approach to Restrictions on School- Sponsored Speech}

\section{Emily Gold Waldman*}

Nearly twenty years ago in Hazelwood School District v. Kuhlmeier, ${ }^{1}$ the Supreme Court - in upholding the constitutionality of a public high school principal's censorship of a student newspaper produced in a journalism class - held that "educators do not offend the First Amendment by exercising editorial control over the style and content of student speech in school-sponsored expressive activities so long as their actions are reasonably related to legitimate pedagogical concerns." ${ }^{2}$ Since then, Hazelwood's "reasonable relat[ion] to legitimate pedagogical concerns" standard has been invoked in a tremendous array of school speech cases. Not only has it been employed in a wide variety of student speech contexts, ${ }^{3}$ but courts have also relied upon it in cases involving public schools' textbook selections and curricular choices, ${ }^{4}$ teachers' in-class speech, ${ }^{5}$ and even the speech of outside entities (such as recruiters and advertisers) in the school setting. ${ }^{6}$

In the process, two major circuit splits have developed. First, the circuits have divided over how far Hazelwood's reach should extend, particularly in terms of whether

\footnotetext{
* Associate Professor of Law, Pace University School of Law, J.D., Harvard Law School, 2002; B.A., Yale University, 1999. Law Clerk to the Honorable Robert A. Katzmann, United States Court of Appeals for the Second Circuit, 2005-2006; Law Clerk to the Honorable William G. Young, United States District Court for the District of Massachusetts, 2002-2003. I thank Jill Gross, Eloise Pasachoff, and Paul Secunda for their helpful comments on this article.

${ }^{1} 484$ U.S. 260 (1988).

${ }^{2} I d$. at 273.

${ }^{3}$ See infra text accompanying notes $60-64 ; 260-91$.

${ }^{4}$ See infra text accompanying notes 66-98.

${ }^{5}$ See infra text accompanying notes $99-157$.

${ }^{6}$ See infra text accompanying notes $158-73$.
} 
Hazelwood is applicable to teachers' classroom speech. ${ }^{7}$ Second, a sharp split has developed over whether Hazelwood goes so far as to permit viewpoint-based speech restrictions, which are generally prohibited under the First Amendment. ${ }^{8}$ Both of these questions have given rise to rich parallel lines of scholarship. ${ }^{9}$ The two issues, however, are rarely considered in tandem.

\footnotetext{
${ }^{7}$ Compare Lacks v. Ferguson Reorganized School Dist. R-2, 147 F.3d 718 (8th Cir. 1998) (applying Hazelwood to teachers' in-class speech); Silano v. Sag Harbor Union Free Sch. Dist. Bd. of Educ., 42 F.3d 719 (2d Cir. 1994) (same); Ward v. Hickey, 996 F.2d 448 (1st Cir. 1993) (same); Bishop v. Aronov, 926 F.2d 1066 (11th Cir. 1991) (same); Miles v. Denver Public Schools, 944 F.2d 773 (10th Cir. 1991) (same); Webster v. New Lenox School Dist. No. 122, 917 F.2d 1004 (7th Cir. 1990) (same); with Mayer v. Monroe Cty. Comm. Sch. Corp., 474 F.3d 477 (7th Cir. 2007) (applying the approach set forth in Pickering v. Board of Education, 391 U.S. 563 (1968), to teachers' in-class speech); Cockrel v. Shelby Cty. Sch. Dist., 270 F.3d 1036 (6th Cir. 2001) (same); Boring v. Buncombe Cty. Bd. of Educ., 136 F.3d 364 (4th Cir. 1998) (en banc) (same); Kirkland v. Northside Independent School Dist., 890 F.2d 794 (5th Cir. 1989) (same). See infra
} text accompanying notes 99-173.

${ }^{8}$ Compare Fleming v. Jefferson Cty. Sch. Dist. R-1, 298 F.3d 918, 928-29 (10th Cir. 2002) (holding that Hazelwood permits viewpoint discrimination); Ward v. Hickey, 996 F.2d 448 (1 st Cir. 2002) (same) with Peck v. Baldwinsville Central Sch. Dist., 426 F.3d 617, 631-633 (2d Cir. 2005) (holding that Hazelwood prohibits viewpoint discrimination); Planned Parenthood of So. Nevada, Inc. v. Clark Cty. Sch. Dist., 941 F.2d 817, 829 (9th Cir. 1991) (same). See infra text accompanying notes 174-92.

${ }^{9}$ On the question of what legal standard should apply to teachers' classroom speech, see, for example, Emily Holmes Davis, Note and Recent Development, Protecting the "Marketplace of Ideas": The First Amendment and Public School Teachers' Classroom Speech, 3 FIRST AMEND. L. REV. 335 (2005); R. Weston Donehower, Note, Boring Lessons: Defining the Limits of a Teacher's First Amendment Right to Speak Through the Classroom, 102 Mich. L. ReV. 517 (2003); Martin H. Redish \& Kevin Finnerty, What Did You Learn in School Today? Free Speech, Values Inculcation, and the Democratic-Educational Paradox, 88 CoRnell L. Rev. 62 (2002); Todd A. DeMitchell, Counterpoint: a New Balance of In-Class Speech: No Longer Just a "Mouthpiece," 31 J. L. \& EdUC. 473 (2002); Karen C. Daly, Balancing Act: Teachers' Classroom Speech and the First Amendment, 30 J.L. \& EDUC. 1 (2001); Theresa J. Bryant, May We Teach Tolerance? Establishing the Parameters of Academic Freedom in Public Schools, 60 U. PITT. L. REV. 579 (1999); William G. Buss, Academic Freedom and Freedom of Speech: Communicating the Curriculum, 2 J. Gender RACE \& Just. 213 (1999) [hereinafter Buss, Academic Freedom]; W. Stuart Stuller, High School Academic Freedom: The Evolution of a Fish Out of Water, 77 NEB. L. Rev. 301 (1998); Gregory A. Clarick, Note, Public School Teachers and the First Amendment: Protecting the Right to Teach, 65 N.Y.U. L. REV. 693 (1990).

As to the viewpoint discrimination issue, see, for example, Lisa Shaw Roy, Inculcation, Bias, and Viewpiont Discrimination in Public Schools, 32 PEPP. L. ReV. 647 (2005); Susannah Barton Tobin, Note, Divining Hazelwood: The Need for a Viewpoint Neutrality Requirement in School Speech Cases, 39 HARV. C.R.-C.L. L. REV. 217 (2004); Katie Hammett, School Shootings, Ceramic Tiles, and Hazelwood: The Continuing Lessons of the Columbine Tragedy, 55 ALA. L. ReV. 393 (2004); Denise Daugherty, Note \& Comment, Free Speech in Public Schools: Has the Supreme Court Created a Haven for Viewpoint Discrimination in School-Sponsored Speech, 20 GA. ST. U. L. REV. 1061 (2004); Samuel P. Jordan, Comment, Viewpoint Restrictions and School-Sponsored Student Speech: Avenues for Heightened Protection, 70 U. CHI. L. Rev. 1555 (2003); Janna J. Annest, Note \& Comment, Only the News That's Fit to Print: The Effect of Hazelwood on the First Amendment Viewpoint-Neutrality Requirement in Public School-Sponsored Forums, 77 WASH. L. ReV. 1227 (2002); William G. Buss, School Newspapers, Public Forum, and the First Amendment, 74 Iowa L. REv. 505 (1989) [hereinafter Buss, School Newspapers]. 
This article argues that these two issues are related in a critical, yet largely unexamined, way: the extension of Hazelwood into contexts beyond the student speech realm has severely muddled the question of whether Hazelwood permits viewpoint-based speech restrictions. Indeed, out of the five circuits that have explicitly reached the question of whether Hazelwood permits viewpoint discrimination, three did so in cases that did not even involve student speech. Moreover, the varying speech contexts in which the circuits have first confronted this question have led to divergent results. The First Circuit, for instance, first addressed the viewpoint discrimination issue in a case where it applied Hazelwood to teacher speech; it concluded that Hazelwood generally permitted viewpoint discrimination. On the other hand, the Ninth and Eleventh Circuits both first reached the question in cases where they applied Hazelwood to the speech of outside entities (respectively, yearbook advertisers and recruiters at a career fair), and they both concluded that Hazelwood generally forbade viewpoint discrimination. This is not a coincidence. Rather, the significantly different interests implicated by teacher speech and outside entity speech directly contributed to these conflicting interpretations of Hazelwood. In short, Hazelwood has been pulled in so many directions that its underlying standard has lost coherence.

In this article, I suggest that this conundrum can be untangled by returning to Hazelwood's core as a student speech case. I first argue that Hazelwood's reach has been significantly over-extended, and that it should be applied only in student speech cases. Not only did Hazelwood arise in the student speech context, but its rationale and approach are in fact uniquely suited to that context. 
Removing these other categories of speech from the Hazelwood equation, in turn, helps shed light on the persistent debate over whether Hazelwood permits viewpointbased discrimination in addition to content-based discrimination. In other words, resolution of the circuit split over Hazelwood's reach helps to resolve the circuit split over whether Hazelwood permits viewpoint-related speech restrictions. Once we return to Hazelwood's origins as a student speech case, and to the text of Hazelwood itself, I argue that it becomes relatively clear that Hazelwood contemplated the permissibility of viewpoint-based restrictions on student speech in certain circumstances. The real issue is not whether viewpoint discrimination is permitted by Hazelwood, but when

Answering this question, in turn, requires a more nuanced analysis of (1) what it means for student speech to occur in a "school-sponsored" context, such that, as the Hazelwood Court put it, "students, parents, and other members of the public might reasonably perceive [the speech] to bear the imprimatur of the school” ${ }^{10}$; and (2) which types of restrictions on student speech are "reasonably related to legitimate pedagogical concerns." I argue that the courts should adopt a sliding-scale approach in which the level of school sponsorship is weighed against the nature of and justification for the speech restriction. Where the perception of school sponsorship is at its highest - because the student speech at issue will affect the substance of other students' classroom learning experience or permanently transform the physical appearance of the school - then a school should receive broad latitude to restrict the speech, even if its restrictions reflect viewpoint-based discrimination. By contrast, where the perception of school imprimatur is lower - because the student speech, despite its occurrence in a school-sponsored context, is clearly attributable to a particular student and will transform neither other

${ }^{10}$ Hazelwood, 484 U.S. at 271. 
students' in-class experience nor the permanent appearance of the school - then any

viewpoint-based restrictions imposed by the school should be subjected to more rigorous examination.

This article proceeds in five parts. First, I discuss the Hazelwood decision in depth. Next, I discuss the various contexts in which Hazelwood has been applied, and the circuit split that has developed over how broadly it should reach. ${ }^{11}$ Third, I describe the circuit split that has developed over whether Hazelwood permits viewpoint-based speech restrictions, highlighting the disparate speech contexts in which the circuits have reached their divergent conclusions. Fourth, I argue that the two splits are linked by a connective thread: the over-extension of Hazelwood. I discuss why Hazelwood is uniquely suited to the student speech context, and why other doctrines - namely, the Pickering-Connick ${ }^{12}$ public employee analysis for teachers' classroom speech and basic public forum analysis for outside entities' speech - provide better frameworks for analyzing school speech restrictions as to non-students, and I draw on the Supreme Court's very recent decision in Garcetti v. Ceballos ${ }^{13}$ to support this view. Finally, having returned to Hazelwood's

\footnotetext{
${ }^{11}$ My discussion, and indeed this entire article, is focused on K-12 public schools, the context in which Hazelwood itself arose. The Seventh Circuit, in an en banc opinion, recently held that Hazelwood is also generally applicable in the university setting, over the objections of a strong dissent. See Hosty v. Carter, 412 F.3d 731 (7th Cir. 2005) (en banc). Several other circuits have also pointed in this direction by invoking Hazelwood in cases involving speech restrictions at the university level. See, e.g., Bishop v. Aronov, 926 F.2d 1066 (11th Cir. 1991); Vanderhurst v. Colorado Mountain College District, 208 F.3d 908 (10th Cir. 2000). Not surprisingly, the question of whether Hazelwood should apply to the university setting, or should instead be limited to the K-12 public school context in which it arose, has given rise to much scholarship, particularly in Hosty's aftermath. See, e.g., Edward L. Carter, Kevin R. Kemper, and Barbara L. Morgenstern, Applying Hazelwood to College Speech: Forum Doctrine and Government Speech in the U.S. Courts of Appeals, 48 S. TEX. L. REV. 157 (2006); Jessica Lyons, Note, Defining Freedom of the College Press After Hosty v. Carter, 59 VAND. L. REv. 1771 (2006). Although I draw upon some of the university cases insofar as they relate to my own discussion of whether Hazelwood should apply to teachers' classroom speech, the separate question of Hazelwood's applicability in the university setting as opposed to the K-12 setting is beyond the scope of this article.

${ }_{12}^{12}$ See Pickering v. Bd. of Educ., 391 U.S. 563 (1968); Connick v. Myers, 461 U.S. 138 (1983).

13126 S. Ct. 1951.
} 
core as a doctrine governing student speech, I set forth my proposal for a sliding-scale framework within which restrictions on student speech can be evaluated.

\section{The Hazelwood Decision}

The Hazelwood dispute began when the principal of Hazelwood East High School - located in St. Louis County, Missouri - received copies of the page proofs for the upcoming May 13, 1983 issue of the Spectrum, Hazelwood East High School's newspaper. ${ }^{14}$ The Spectrum was written and edited by the students in the high school's Journalism II class, and was largely funded by the district's Board of Education. ${ }^{15}$ A faculty member served as the journalism teacher and newspaper adviser, and typically provided the principal with copies of the page proofs for review prior to each issue's publication. ${ }^{16}$

When Hazelwood East's principal saw the copies of the May 13 page proofs, he was troubled by two of the articles. One article discussed three pregnant students at the high school, and the principal was concerned that the references to sexual activity and birth control were inappropriate for some of the school's younger students and that the students might be identifiable from the text, even though pseudonyms had been used. ${ }^{17}$ The other article discussed the impact of divorce on some students at the school; here, the principal was concerned that the article included a student's complaints about her father without having provided her parents with an opportunity to respond to these comments or to consent to their publication. ${ }^{18}$ Believing that there was no time to make changes to these stories, the principal ordered the faculty adviser to pull the pages from the issue on

\footnotetext{
${ }^{14} I d$. at 263.

${ }^{15} \mathrm{Id}$. at $262-63$.

${ }^{16} I d$. at 263.

${ }^{17} \mathrm{Id}$.

${ }^{18} \mathrm{Id}$. at 263-64.
} 
which these two articles appeared. ${ }^{19}$ The adviser complied, and the issue was released without the two pages in question. ${ }^{20}$ Three students on the Spectrum staff then filed suit, alleging that the censorship of these articles had violated their First Amendment rights. ${ }^{21}$

At the time the Hazelwood East students filed their lawsuit, there was a single Supreme Court decision addressing school restrictions on student speech: Tinker v. Des Moines Independent Community School District. ${ }^{22}$ There, the Supreme Court had upheld the right of students to wear black armbands to school in protesting the Vietnam War. ${ }^{23}$ Stating that "[i]t can hardly be argued that either students or teachers shed their constitutional rights to freedom of speech or expression at the schoolhouse gate, ${ }^{, 24}$ the Court concluded that the students had a constitutional right to wear their armbands (which the Court deemed "pure speech" ${ }^{, 25}$ ) unless doing so would "materially and substantially" disrupt the work of the school or invade the rights of others. ${ }^{26}$ Thus, because the armbands, while causing "discussion outside of the classrooms," had not disrupted classroom work nor intruded upon the lives of others, they had to be allowed. ${ }^{27}$

Applying Tinker to the Hazelwood dispute, the Eighth Circuit concluded that the high school principal's censorship of two pages in the Spectrum had been unconstitutional, reversing the district court's ruling that the censorship was justified. ${ }^{28}$ The court held that the Spectrum had functioned as a public forum for student viewpoints, and that there was no reasonable basis upon which the principal could have forecast that

${ }^{19} I d$. at 264.

${ }^{20} I d$.

${ }^{21} \mathrm{Id}$.

22393 U.S. 503 (1969).

${ }^{23} \mathrm{Id}$. at 514 .

${ }^{24} I d$. at 506.

${ }^{25} \mathrm{Id}$. at 508 .

${ }^{26} I d$. at 513.

${ }^{27} I d$. at 514.

${ }^{28}$ Kuhlmeier v. Hazelwood School Dist., 795 F.2d 1368, 1374-76 (8th Cir. 1986). Id. at 1374. 
the publication of the articles "would have materially disrupted classwork or given rise to substantial disorder in the school. ${ }^{29}$ Nor would the articles' publication have met the alternative justification recognized by Tinker: the invasion of the rights of other students, which the Eighth Circuit narrowly construed as referring only to situations in which "publication of th[e] speech could result in tort liability for the school." ${ }^{\text {30 }}$ Accordingly, the court ruled in the Hazelwood students' favor on their First Amendment claim, prompting the school district to file a petition for certiorari, which was granted.

By the time Hazelwood reached the Supreme Court a year later, the Supreme Court had issued a second decision involving students' First Amendment rights: Bethel School District No. 403 v. Fraser. ${ }^{31}$ In Fraser, a high school student had been disciplined for the speech that he delivered at a school assembly, in which he nominated a fellow student for a student elective office. ${ }^{32}$ His speech used an "elaborate, graphic, and explicit sexual metaphor": he stated the candidate was "firm in his pants...a man who takes his point and pounds it in ... who will go to the very end - even the climax, for each and every one of you. ${ }^{, 33}$ After the school punished him for giving the speech, the student filed suit, alleging a First Amendment violation. ${ }^{34}$ Although the Ninth Circuit applied Tinker and affirmed the lower court's ruling in the student's favor, the Supreme Court reversed. ${ }^{35}$ Rather than applying Tinker's material disruption/invasion of rights test, the Fraser Court essentially deemed Tinker inapplicable, emphasizing the "marked distinction between the political 'message' of the armbands in Tinker and the sexual

\footnotetext{
${ }^{29} I d$. at 1375 .

${ }^{30} \mathrm{Id}$. at 1376.

${ }^{31} 478$ U.S. 675 (1986).

${ }^{32} \mathrm{Id}$. at 677.

${ }^{33} I d$. at 678; id. at 687 (Brennan, $J$., dissenting).

${ }^{34} \mathrm{Id}$. at 670 .

${ }^{35} \mathrm{Id}$. at $679-80$.
} 
content of respondent's speech in this case." ${ }^{36}$ Emphasizing that "the penalties imposed in this case were unrelated to any political viewpoint," the Court concluded that the First Amendment did not "prevent school officials from determining that to permit a vulgar and lewd speech such as respondent's would undermine the school's basic educational mission."37 It thus rejected the student's First Amendment argument and ruled in the school district's favor. ${ }^{38}$

Hazelwood presented yet a third factual variation. Unlike Fraser, the speech at issue was not lewd or vulgar. And unlike Tinker, the speech was not simply the personal expression of individual students; it was instead being communicated through a schoolsponsored activity: a newspaper produced by a journalism class. Pulling together strands of Tinker and Fraser, the Hazelwood Court began by noting that although public school students did not "shed their constitutional rights to freedom of speech or expression at the schoolhouse gate," the First Amendment rights of students in the public schools were "not automatically coextensive with the rights of adults in other settings." Hazelwood Court went on - in section II.A of its analysis ${ }^{40}-$ to conclude, through application of general public forum doctrine, that the Spectrum was not a forum for public expression by students. ${ }^{41}$ Rather, it was "part of the educational curriculum and a "regular classroom activity.",42 This, in turn, led the Court to conclude that "school

\footnotetext{
${ }^{36} I d$.

${ }^{37} I d$. at 685 .

${ }^{38} I d$. at 687.

${ }^{39}$ Hazelwood, 484 U.S. at 266.

${ }^{40}$ I note the headings that the Hazelwood Court used to structure its opinion because, as discussed infra, I believe that they help clarify the scope of the Court's holding. See infra text accompanying notes 219-221.

${ }^{41} I d$. at $267-270$.

${ }^{42} I d$. at 268.
} 
officials were entitled to regulate the contents of the Spectrum in any reasonable manner."43

What, then, qualified as a "reasonable manner" of regulation? In section II.B, the Hazelwood Court left general public forum doctrine behind to address this issue. First, the Court again emphasized the distinction between "whether the First Amendment requires a school to tolerate particular student speech" (the Tinker question) and "whether the First Amendment requires a school affirmatively to promote student speech" (the Hazelwood question). ${ }^{44}$ The Court explained:

The former question addresses educators' ability to silence a student's personal expression that happens to occur on the school premises. The latter question concerns educators' authority over school-sponsored publications, theatrical productions, and other expressive activities that students, parents, and members of the public might reasonably perceive to bear the imprimatur of the school. These activities may fairly be characterized as part of the school curriculum, whether or not they occur in a traditional classroom setting, so long as they are supervised by faculty members and designed to impart particular knowledge or skills to student participants and audiences. ${ }^{45}$

As to this latter category of speech, the Court concluded that educators could impose restrictions "as long as their actions are reasonably related to legitimate pedagogical concerns." ${ }^{46}$ Such concerns included, for instance, (1) ensuring that "participants learn whatever lessons the activity is designed to teach"; (2) shielding readers and listeners from material that might "be inappropriate for their level of maturity," and (3) generally

\footnotetext{
${ }^{43} I d$. at 270. As discussed further below, the Supreme Court explained that public schools are not traditional public forums (such as streets, parks, and the like), and can be deemed "public forums only if school authorities have 'by policy or practice' opened those facilities 'for indiscriminate use by the general public' ... or by some segment of the public such as student organizations. If the facilities have instead been reserved for other intended purposes, 'communicative or otherwise,' then no public forum has been created, and school officials may impose reasonable restrictions on the speech of students, teachers, and other members of the school community." Id. at 267 (citing Perry Education Assoc. v. Perry Local Educators Assoc., 460 U.S. 37, 47 (1983)).

${ }^{44} I d$. at 270-71.

${ }^{45} I d$. at 271.

${ }^{46} I d$. at 273.
} 
disassociating the school from any speech that (a) was "ungrammatical, poorly written, inadequately researched, biased, or prejudiced, vulgar or profane," (b) could be seen as "advocat[ing] drug or alcohol use, irresponsible sex, or conduct otherwise inconsistent with the shared values of a civilized social order," or (c) could "associate the school with any position other than neutrality on matters of political controversy.,

In justifying this approach, the Hazelwood Court highlighted the negative consequences that it envisioned were schools not granted this level of discretion over school-sponsored student speech. First, the schools would be constrained from their role as a "principal instrument in awakening the child to cultural values, in preparing him for later professional training, and in helping him to adjust normally to his environment." Second, in direct response to the dissent's suggestion that Tinker uniformly provided the appropriate test for school restrictions on student speech, ${ }^{49}$ the Court argued that this would require schools to "open their newspapers to all student expression that does not threaten 'material disruption of classwork' or violation of 'rights that are protected by law,' regardless of how sexually explicit, racially intemperate, or personally insulting that expression otherwise might be. ${ }^{, 50}$ Schools would likely prefer to shut student newspapers down altogether, the Court predicted, rather than permitting such views to be circulated under their auspices. ${ }^{51}$

Pursuant to its newly-articulated "reasonable relation to a legitimate pedagogical concern" test, the Hazelwood Court proceeded to rule in favor of the school district. ${ }^{52}$ As

${ }^{47} I d$. at $271-72$.

${ }^{48}$ Id. at 272.

${ }^{49} I d$. at 283 (Brennan, $J$., dissenting).

${ }^{50} I d$. at 276 \& n. 9.

${ }^{51} I d$.

${ }^{52} I d$. at $274-76$. 
to the teen pregnancy article, the Court held that the principal's censorship was reasonably related to shielding "14-year-old freshmen" and perhaps their "even younger brothers and sisters," who might read the paper if it were brought home, from the article's frank discussion of the teenage girls' sexual histories and use or non-use of birth control. ${ }^{53}$ Additionally, the Court stated that the principal might reasonably have been concerned that the article had failed to adequately protect the teenage girls' anonymity or to provide their boyfriends and parents (who were mentioned in the article) the chance to offer a response or consent to the publication. ${ }^{54}$ Similarly, as to the divorce article, the Court found that the principal could reasonably have concluded that the student's father was entitled to an opportunity to defend himself as a matter of journalistic fairness." The Court thus concluded that the principal "could reasonably have concluded that these articles had not sufficiently mastered those portions of the Journalism II curriculum that pertained to the treatment of controversial issues and personal attacks." ${ }^{, 56}$ This, in turn, made the principal's censorship of the articles reasonably related to legitimate pedagogical concerns, and therefore constitutional. ${ }^{57}$

\section{Hazelwood's Broad Reach}

Hazelwood immediately changed the landscape for assessing the constitutionality of school restrictions on student speech. Taken together, Tinker and Hazelwood essentially divided the student speech universe in two: student speech that merely occurred on school premises could only be restricted if it caused a material disruption or

\footnotetext{
${ }^{53}$ Id. at 274-75.

${ }^{54} \mathrm{Id}$. at 274.

${ }^{55} \mathrm{Id}$. at 275.

${ }^{56} \mathrm{Id}$. at 276.

${ }^{57}$ Id.
} 
invaded others' rights; while student speech disseminated through a school-sponsored context could be restricted as long as the school had a legitimate pedagogical reason for doing so. ${ }^{58}$ Hazelwood itself made clear that this latter category should be construed broadly, encompassing not only classroom activities and official school-sponsored publications and productions, but also any "other expressive activities that students, parents, and members of the public might reasonably perceive to bear the imprimatur of the school," provided that they are supervised by faculty members and designed to teach particular knowledge or skills to students. ${ }^{59}$

And, indeed, over the past nineteen years, Hazelwood has been invoked in a tremendous array of student speech cases, in almost every conceivable context from the kindergarten to the high school level. Examples, each of which I return to in Section V, include:

- A kindergartner who sued when, after he created a poster for a school assignment to illustrate ways of saving the environment, his school displayed his poster in a way that concealed its depiction of Jesus Christ; ${ }^{60}$

- An elementary school student who sued when his school refused to allow him to distribute candy canes with religious messages during a classroom holiday party ${ }^{61}$

- A high school student who sued when his school disqualified his candidacy for student council presidency after he delivered a speech at a school assembly

\footnotetext{
${ }^{58}$ Fraser, in turn, can be viewed as applying to the sub-category of cases in which the speech at issue is so vulgar and offensive, and so lacking in political content, that no constitutional protection attaches when it is uttered in the school setting. Of course, had Fraser been decided after Hazelwood, perhaps the Supreme Court would have simply applied Hazelwood (given that the speech was delivered at a school-sponsored assembly) and upheld the restriction as reasonably related to a legitimate pedagogical purpose. Indeed, the Fraser Court gestured toward the importance of school sponsorship in stating that "[a] high school assembly or classroom is no place for a sexually explicit monologue." Fraser, 478 U.S. at 685 . The Fraser Court did not, however, rest its holding on the fact of school sponsorship, a concept that did not come fully into focus until Hazelwood.

${ }^{59}$ Hazelwood, 484 U.S. at 271.

${ }^{60}$ Peck v. Baldwinsville Central School District, 426 F.3d 617 (2d Cir. 2005) (holding that the school's actions did not satisfy Hazelwood). See infra text accompanying notes 184-85; 285-89.

${ }^{61}$ Walz v. Egg Harbor Township Bd. of Educ., 342 F.3d 271 (holding that the school's actions satisfied Hazelwood) (3d Cir. 2003). See infra text accompanying notes 274-78.
} 
in which he stated, among other things, that "[ $\mathrm{t}]$ he administration plays tricks with your mind and they hope you won't notice. For example, why does [the assistant principal] stutter when he is on the intercom? He doesn't have a speech impediment. If you want to break the iron grip of this school, vote for me for president.",62

- Several Columbine High School students and their parents, who sued when the school refused to hang the tiles that they had created as part of a tilepainting project to commemorate the April 1999 massacre carried out by two Columbine students; ${ }^{63}$ and

- A high-school student who sued after her school removed the religious murals that she had painted on school walls as part of a high school beautification project. $^{64}$

As disparate as these cases are, they all share a common thread: they involve restrictions on student speech in various school-sponsored contexts. It makes perfect sense, then, that Hazelwood was employed to assess each of these disputes.

More surprising, however, is that numerous courts have also been applying Hazelwood in cases that do not involve student speech. Indeed, in 1992 - a mere four years after Hazelwood was decided - Rosemary Salomone described this trend, writing that "just about any aspect of school sponsored activity (newspapers, career days, elective courses) conducted anywhere in the school (classrooms, hallways) is considered to be a nonpublic forum subject to the reasonableness standard of Hazelwood."65 This phenomenon has only increased since then, with numerous courts apparently concluding that all speech that can be considered "school sponsored" - regardless of whether it is student speech, teacher classroom speech, outside entity speech, or speech that reflects

\footnotetext{
${ }^{62}$ Poling v. Murphy, 872 F.2d 757 (6th Cir. 1989) (holding that the school's actions satisfied Hazelwood). See infra text accompanying notes 290-92.

${ }^{63}$ Fleming v. Jefferson Cty. Sch. Dist., 298 F.3d 918 (10th Cir. 2002) (holding that school's actions satisfied Hazelwood). See infra text accompanying notes 189-91; 279-83.

${ }^{64}$ Bannon v. Sch. Dist. of Palm Beach Cty., 387 F.3d 1208 (11th Cir. 2004) (holding that the school's actions satisfied Hazelwood). See infra text accompanying notes 203-16; 279-83.

${ }^{65}$ Rosemary C. Salomone, Free Speech and School Governance in the Wake of Hazelwood, 26 GA. L. REV. 253, 316 (1992).
} 
district-level decisions about textbooks and curricula - falls under Hazelwood's umbrella. Below, in order to set the stage for my argument, I discuss the various non-studentspeech contexts in which Hazelwood has been applied, and the circuit splits that have developed in each of these areas.

\section{A. Textbook/Curriculum Section}

The courts are generally conflicted about whether Hazelwood's "reasonable relat[ion] to a legitimate pedagogical purpose" standard applies to school districts' decisions about textbooks and curricula, sometimes even issuing mixed messages within a single opinion. Those courts that have concluded that Hazelwood is inapplicable here have done so on the explicit grounds that textbook and curricular decisions simply reflect pure government speech, and thus cannot violate the speech rights of others. By contrast, the courts that have applied Hazelwood here seem to have implicitly interpreted Hazelwood as announcing a generally applicable "reasonableness" standard for all school district decisions about speech-related matters. Although the splits over textbooks and curricula have not yet entirely risen to the surface, an examination of the decisions on this topic makes clear that divisions are percolating.

As to textbook selection, only two circuits have reached the issue of whether Hazelwood applies, and they have reached opposite conclusions. The Fifth Circuit recently confronted this question in Chiras v. Miller ${ }^{66}$ in which a textbook author and high school student brought First Amendment claims after the Texas State Board of Education refused to approve the textbook author's environmental science textbook. ${ }^{67}$ The plaintiffs argued that this refusal, which they alleged to have stemmed from the

\footnotetext{
${ }^{66} 432$ F.3d 606 (5th Cir. 2005).

${ }^{67} \mathrm{Id}$. at $607-608$.
} 
influence of conservative think tanks, violated Hazelwood. ${ }^{68}$ The Fifth Circuit, noting that "there is no strong consensus among the circuit courts regarding the application of First Amendment principles to the selection of curricular materials by school boards," engaged in a detailed analysis of whether Hazelwood was applicable here. ${ }^{69}$ It held that it was not, stating that when the Board of Education "devises the curriculum for Texas and selects the textbook with which teachers will teach [] the students, it is the state speaking." ${ }^{70}$ This rendered Hazelwood inapplicable, the Fifth Circuit reasoned, because a "necessary precondition" of Hazelwood was that some sort of forum for the expression of others had been created in the first place. ${ }^{71}$

The Fifth Circuit acknowledged, however, that this conclusion conflicted with that reached by the Eleventh Circuit in Virgil v. School Board of Columbia County. ${ }^{72}$ There, when parents filed suit after the school board removed a previously approved textbook from an elective high school course due to complaints from other parents that the book contained sexually explicit material (namely, passages from Lysistrata and The Miller's Tale), the Eleventh Circuit concluded that Hazelwood provided "direct guidance.",73 It broadly characterized Hazelwood as "establish[ing] a relatively lenient test for regulation of expression which 'may fairly be characterized as part of the school curriculum," and did not discuss Hazelwood's specific genesis in the student speech context. $^{74}$ In applying Hazelwood, the Virgil court ultimately concluded that the Board's action was constitutional, stating that the textbook decision was a curricular decision that

\footnotetext{
${ }^{68} \mathrm{Id}$. at $609-611$.

${ }^{69} \mathrm{Id}$. at $614-16$.

${ }^{70} \mathrm{Id}$. at 614.

${ }^{71} I d$. at 617 .

${ }_{72}^{72}$ Id. (citing Virgil v. Sch. Bd. of Columbia Cty., 862 F.2d 1517 (11th Cir. 1989)).

${ }^{73}$ Virgil, 862. F.2d at 1521.

${ }^{74}$ Id.
} 
would be perceived as bearing the imprimatur of the school, and that it had been reasonably related to legitimate pedagogical concerns - namely, the "explicit sexuality and excessively vulgar language in the selections. ${ }^{, 75}$ Thus, although both the Fifth and Eleventh Circuits reached the same ultimate results - upholding the constitutionality of the school districts' actions - they took divergent routes in getting there.

The case law surrounding Hazelwood's applicability to curriculum selection is murkier. The Third Circuit has essentially staked out the position that Hazelwood's reasonableness standard does not apply to curricular decisions. It adopted this view in one of the first post-Hazelwood cases to raise this issue: Bradley v. Pittsburgh Board of Education. ${ }^{76}$ There, a high school teacher brought a First Amendment claim after her school prohibited her from organizing her classroom according to the "Learnball" technique, which involved dividing the class into teams, giving students the opportunity to elect their team leaders and establish class rules, and setting up a system of rewards including radio playing in the classroom. ${ }^{77}$ "[W]e do not have to delineate the scope of academic freedom afforded to teachers under the First Amendment" here, the Third Circuit ruled, because "no court has found that teachers' First Amendment rights extend to choosing their own curriculum or classroom management techniques in contravention of school policy or dictates. ${ }^{, 78}$ In 1998, the Third Circuit reaffirmed this view in Edwards v. California University of Pennsylvania,${ }^{79}$ holding - in an opinion authored by then-Judge Alito - that Hazelwood did not apply to school administrators' decisions

\footnotetext{
${ }^{75}$ Id. at 1522-23. The Virgil Court explained that it was not applying the Supreme Court's 1982 decision in Board of Education v. Pico, 457 U.S. 853 (1982), which had related to the removal of books from a school library, and which, as the Virgil court noted, had taken "special note of the "unique role of the school library' as a repository for 'voluntary inquiry." Id. at $1524 \&$ n.8 (citing Pico, 457 U.S. at 869).

${ }^{76} 910$ F.2d 1172 (1990).

${ }^{77} \mathrm{Id}$. at $1174-75$.

${ }^{78} \mathrm{Id}$. at 1176.

${ }^{79} 156$ F.3d 488 (3d Cir. 1998).
} 
about "what will be taught in the classroom," and that it therefore did not need to engage in the Hazelwood analysis. ${ }^{80}$

Subsequent to the Bradley Court's 1990 pronouncement that no court had recognized teachers' First Amendment rights to choose their own curriculum, some courts did begin to move in that direction. In particular, the Tenth Circuit suggested in Vanderhurst v. Colorado Mountain College District ${ }^{81}$ that it disagreed with the argument that "a teacher enjoys no First Amendment right to determine the educational content of a course," noting the Supreme Court's statement in Keyishian v. Board of Regents (a case involving a challenge brought by public university professors to a state law requiring them to certify that they were not Communists) that academic freedom is "a special concern of the First Amendment, which does not tolerate laws that cast a pall of orthodoxy over the classroom." ${ }^{.82}$ The Vanderhurst Court went on to state that, at least for purposes of the instant case, it viewed Hazelwood as providing the appropriate standard for assessing whether the termination of an instructor who had "attempt[ed] to communicate course content at odds with the chosen curriculum" was constitutional. ${ }^{83}$

Other courts have issued mixed messages as to whether Hazelwood applies to curricular choices, suggesting both that curricular choices reflect pure government speech and that Hazelwood is still somehow applicable. In Bishop v. Aronov ${ }^{84}$ for example, the Eleventh Circuit stated both that Hazelwood was applicable to a case involving a school's

\footnotetext{
${ }^{80} I d$. at 491 . Edwards arose in the public university context, and thus presumably would apply with equal (if not greater) force in the $\mathrm{K}-12$ setting.

${ }^{81} 208$ F.3d 908 (10th Cir. 2000).

${ }^{82}$ Id. at 913 (citing Keyishian v. Board of Regents, 385 U.S. 589, 597 (1967)).

${ }^{83} \mathrm{Id}$. at 913-914. The court noted that both sides had "embrace[d] the [Hazelwood] approach as the proper means to analyze Vanderhurst's First Amendment claim." Id. at 914-15.

${ }^{84} 926$ F.2d 1066 (11th Cir. 1991).
} 
restrictions on the content of a particular course, ${ }^{85}$ and that when a teacher and school disagree about the content of a course, the school "must have the final say," because schools must have "command of their own courses." "86 Similarly, a recent Northern District of California decision first stated that "teachers do not have a first amendment right to determine what curriculum will be taught in the classroom," ${ }^{87}$ but then also stated that the plaintiff teacher (who had sued over restrictions placed on his use of supplemental classroom materials that had religious content) "might still state a claim if he alleges restrictions which are not 'reasonably related to legitimate pedagogical concerns." ",88

The most recent development on this front comes from the Seventh Circuit, which had initially straddled the line as to whether Hazelwood applied to curricular choices, but implicitly retreated from this position in January 2007. In Webster v. New Lenox School District, ${ }^{89}$ a 1990 case in which a teacher alleged that his First Amendment rights had been violated when the school district prohibited him from teaching creationism in the classroom, ${ }^{90}$ the Seventh Circuit issued an ambiguous decision. It first stated that the school board had the authority "to set the curriculum," and that the "first amendment is not a teacher license for uncontrolled expression at variance with established curricular content." 92 But it then proceeded to apply Hazelwood, stating that that the school district's prohibition on the teaching of creationism had been related to the school board's important and legitimate pedagogical interest in avoiding an Establishment Clause

\footnotetext{
${ }^{85}$ Id. at 1074 .

${ }^{86} \mathrm{Id}$. at 1076 .

${ }^{87}$ Williams v. Vidmar, 367 F. Supp. 2d 1265, 1271 (N.D. Cal. 2005).

${ }^{88} I d$. at 1273 .

${ }^{89} 917$ F.2d 1004 (7th Cir. 1990).

${ }^{90} \mathrm{Id}$. at 1006.

${ }^{91} \mathrm{Id}$. at 1007.

${ }^{92} I d$. (internal citation and quotation marks omitted).
} 
violation. ${ }^{93}$ The Seventh Circuit thus left unclear whether it had invoked Hazelwood at the end of its decision essentially to gild the lily, or whether it genuinely believed that the school district needed to satisfy the Hazelwood standard in order to prevail against the teacher's claim. In the 2007 case of Mayer v. Monroe County Community School Corporation $^{94}$ - which involved the related issue of constitutional protection for teachers' classroom speech - the Seventh Circuit essentially answered that question. Characterizing Webster as simply having held that the teacher "did not have a constitutional right to introduce his own views on the subject but must stick to the prescribed curriculum - not only the prescribed subject matter, but the prescribed perspective on that subject matter, the Mayer court did not even acknowledge Webster's previous invocation of Hazelwood..$^{95}$ Mayer thus suggests that to the extent the Seventh Circuit previously deemed Hazelwood applicable to curricular choices, it no longer does so. ${ }^{96}$

Given the evolving and sometimes amorphous nature of circuit decisions on this issue, it is hard to draw firm classifications as to which circuits view Hazelwood as fully applicable to curricular selections. Much of the murkiness, I believe, stems from the fact that the curricular selection question often blends into the question of when schools can constitutionally restrict teachers' in-school speech. While the Third Circuit in Bradley gestured toward distinguishing between these two issues, ${ }^{97}$ the Seventh, Tenth, and

\footnotetext{
${ }^{93}$ Id. at 1008 .

94 474 F.3d 477 (7th Cir. 2007).

${ }^{95}$ Mayer v. Monroe Cty. Comm. Sch. Corp., 474 F.3d 477, 479 (7th Cir. 2007). For further discussion of this opinion, see infra text accompanying notes 140-41; 242-45.

${ }^{96}$ As I argue infra, this development accords with the Supreme Court's recent holding in Garcetti v. Ceballos, 126 S. Ct. 1951 (2006). See infra text accompanying notes 239-45.

${ }^{97}$ Bradley v. Pittsburgh Bd. of Educ., 910 F.3d 1172, 1176 (suggesting that even if teacher possess some academic freedom under the First Amendment, "no court has found that teachers' First Amendment rights extend to choosing their own curriculum").
} 
Eleventh Circuits have drawn no such distinction. ${ }^{98}$ As such, turning to an assessment of the circuit split over whether Hazelwood applies to teachers' in-school speech helps to shed light on the incipient split over curriculum selection.

\section{B. Teachers' Classroom Speech}

The division among the circuits as to Hazelwood's reach is starker when it comes to public school teachers' in-class speech, but it continues to evolve. Since Hazelwood was decided, the First, Second, Eighth, Tenth, and Eleventh Circuits have explicitly applied it to restrictions on teachers' in-school speech (regardless of whether that speech related to curricular decisions or consisted of stray classroom comments), while the Fourth, Fifth, and Sixth Circuits have instead chosen to apply the approach set forth in Pickering v. Board of Education ${ }^{99}$ and its progeny for assessing the constitutionality of speech restrictions on public employees. Most recently, as noted above and discussed further below, the Seventh Circuit, having previously applied Hazelwood to teachers' classroom speech, suddenly switched gears and applied Pickering instead. Meanwhile, the Third and Ninth Circuits have not definitively weighed in (although there are clues as to their inclinations) on the issue, and the D.C. Circuit has not reached it.

\footnotetext{
${ }^{98}$ For example, the Vanderhurst court, when suggesting that Hazelwood should apply to the plaintiff teacher's choices about what substantive curricular content to cover in his class, directly invoked a line of cases holding that Hazelwood applies to teachers' classroom comments. Vanderhurst, 208 F.3d at 914. In particular, the Vanderhurst court focused on the Tenth Circuit's previous decision in Miles v. Denver Public Schools, 944 F.2d 773 (10th Cir. 1991), which, as discussed infra, had held Hazelwood applicable in a case involving a teacher's offhand classroom comment about two particular students (and did not present any issues relating to curricular selections). Id. Similarly, the Aronov court viewed the curriculum content issue as ultimately reducing to the question of "to what degree a school may control classroom instruction before touching the First Amendment rights of a teacher," thus drawing no distinction between curricular issues and classroom speech issues. Aronov, 926 F.2d at 1073. By the same token, even though Mayer involved not a teacher's curricular selection but rather an isolated classroom comment about the teacher's personal opposition to the war in Iraq, the Seventh Circuit nonetheless fell back on the principle that a teacher must teach whatever curriculum the board describes.

99391 U.S. 563 (1968).
} 
The initial circuit to apply Hazelwood to teachers' in-school speech was the Seventh Circuit in its 1990 Webster decision, which - as noted above - briefly referred to Hazelwood at the very end of its opinion about school restrictions on the teaching of creationism. ${ }^{100}$ The Eleventh Circuit similarly invoked Hazelwood the following year in Aronov, in which it acknowledged that Hazelwood had addressed restrictions on student speech rather than teacher speech, but stated that "insofar as [Hazelwood] covers the extent to which an institution may limit in-school expressions which suggest the school's approval, we adopt the Court's reasoning as suitable to our ends."

Shortly thereafter, the Tenth Circuit followed suit in Miles v. Denver Public Schools. ${ }^{102}$ There, a public high school teacher sued after being disciplined for commenting to his ninth grade government class that "I don't think in 1967 you would have seen two students making out on the tennis court."103 This comment - a reference to a widely-circulated rumor that two students had been seen having sex on the tennis court the previous day - prompted complaints from the parents of the two students in question. ${ }^{104}$ In assessing the teacher's claim that the resultant discipline had violated his First Amendment rights, the Tenth Circuit deemed Hazelwood applicable. ${ }^{105}$ It acknowledged that Hazelwood had involved student speech rather than teacher speech, but stated that "we find no reason to distinguish between the classroom discussion of students and teachers in applying Hazelwood here. A school's interests in regulating classroom speech ... are implicated regardless of whether that speech comes from a

\footnotetext{
${ }^{100}$ Webster v. New Lenox Sch. Dist., 917 F.2d 1004, 1008 (7th Cir. 1990).

${ }^{101}$ Bishop v. Aronov, 926 F.2d 1066, 1074 (11th Cir. 1991).

102944 F.2d 773 (10th Cir. 1991).

${ }^{103} \mathrm{Id}$. at 774 .

${ }^{104}$ Id.

${ }^{105}$ Id. at 775.
} 
teacher or student." 106 The court further found that Hazelwood was satisfied here, because the impetus for the discipline had been reasonably related to the school's pedagogical interests. $^{107}$

In subsequent years, several circuits joined the trend of applying Hazelwood to teacher speech. In 1993, expressly relying on Miles, the First Circuit concluded in Ward v. Hickey ${ }^{108}$ that Hazelwood should apply where a nontenured teacher sued her school district when it chose not to reappoint her because of a discussion that she had engaged in with her ninth grade biology class about the abortion of fetuses with Down's Syndrome. ${ }^{109}$ Citing Miles, the First Circuit reasoned that "a teacher's statements in class during an instructional period are ... part of a curriculum and a regular class activity. Like [Hazelwood's] school newspaper, the classroom is not a public forum, and therefore is subject to reasonable speech regulation."110 The Second Circuit followed suit in $1994,{ }^{111}$ as did the Eighth Circuit in $1998 .^{112}$

By contrast, the Fourth, Fifth, Sixth, and Seventh Circuits have explicitly held that the 1967 Pickering decision - which first set out the framework for assessing the constitutionality of speech restrictions on public employees - applies with full force to restrictions on teachers' in-school speech. Pickering, interestingly enough, itself

\footnotetext{
${ }^{106}$ Id. at 777 . The court also stated that "[w]e are convinced that if students' expression in a school newspaper bears the imprimatur of the school, then a teacher's expression in the "traditional classroom setting' also bears the imprimatur of the school." Id. at 776.

${ }^{107}$ Id. at 778-79.

108996 F.2d 448 (1st Cir. 1993).

${ }^{109} \mathrm{Id}$. at $450-453$.

${ }^{110} I d$. at 453 . Ward ended up being decided on rather unusual grounds. Evidently, the teacher did not even try to argue on appeal that the school "was not entitled to limit her statements." Id. at 454. Instead, she argued only that the school had "failed to notify her that her conduct was prohibited." Id. The First Circuit agreed that she had possessed a First Amendment right "to know what conduct is proscribed" and that the school was "not entitled to retaliate against speech that it never prohibited," $i d$. at 453-54-a holding that not many other courts have reached. It concluded, however, that she had waived the issue by failing to sufficiently raise it below. $I d$. at 455 .

${ }^{111}$ Silano v. Sag Harbor Union Free Sch. Dist. Bd. of Educ., 42 F.3d 719, 723 (2d Cir. 1994).

${ }^{112}$ Lacks v. Ferguson Reorganized School District R-2, 147 F.3d 718,724 (8th Cir. 1998).
} 
involved the speech of a public school teacher, although not in the classroom: the plaintiff was a public school teacher dismissed after sending a letter to a local newspaper that criticized the school board's funding decisions. ${ }^{113}$ The Pickering Court held that this termination had violated the teacher's First Amendment rights, explaining that a balance must be struck "between the interests of the teacher, as a citizen, in commenting upon matters of public concern and the interest of the State, as an employer, in promoting the efficiency of public services it performs through its employees." "114 It concluded that the teacher had spoken as a "member of the general public" about an issue of public concern, that the school district could not show that the teacher's letter had caused any disruption, and that his speech had therefore been constitutionally protected. ${ }^{115}$ The Court further refined this approach in Connick v. Myers,${ }^{116}$ developing a two-pronged test for assessing the free speech claims of public employees. The initial threshold question, the Court explained, is whether the employee was speaking as a citizen on a matter of public concern; if not, then the First Amendment claim fails at that juncture. ${ }^{117}$ If so, then the court must proceed to an evaluation of whether the employee's First Amendment interest in making the speech in question outweighed the employer's justification for limiting it, an assessment commonly referred to as "Pickering balancing." 118 In 2006, the Supreme

\footnotetext{
${ }^{113}$ Pickering, 391 U.S. at 564-66.

${ }^{114} \mathrm{Id}$. at 568 .

${ }^{115} \mathrm{Id}$. at $572-74$.

${ }^{116} 461$ U.S. 138 (1983).

${ }^{117} \mathrm{Id}$. at 147 (stating that "when a public employee speaks not as a citizen upon matters of public concern, but instead as an employee upon matters of personal interest, absent the most unusual circumstances, a federal court is not the appropriate forum in which to review the wisdom of a personnel decision taken by a public agency allegedly in reaction to the employee's behavior").

${ }^{118} I d$. at 148-154 (explaining that when the public employee has spoken as a citizen on a matter of public concern, the question becomes whether the government was justified in disciplining the employee, which requires the court to engage in a "particularized balancing" that considers "the government's interest in the effective and efficient fulfillment of its responsibilities to the public" as well as the extent to which the speech "involved matters of public concern").
} 
Court further refined this approach in Garcetti v. Ceballos, ${ }^{119}$ emphasizing that the initial threshold inquiry primarily rests on whether the employee was speaking in his capacity as a citizen, rather than on whether the speech related to a matter of public concern. ${ }^{120}$

The Fifth Circuit was the first to adopt the view that the Pickering-Connick framework applied to restrictions on teachers' in-class speech, holding in 1989 in Kirkland v. Northside Independent School District ${ }^{121}$ that this framework applied to a teacher's claim that he had been dismissed for using an unapproved reading list. ${ }^{122}$ The Kirkland court further concluded that the teacher's use of his own unapproved reading list did not raise a matter of public concern, particularly given that he had never spoken out in public about it or attempted to obtain approval for it. ${ }^{123}$ The court thus concluded that his claim could not pass the initial threshold for First Amendment protection, and did not proceed to a balancing inquiry. ${ }^{124}$ Although the court mentioned Hazelwood in passing, it did not substantively evaluate whether Hazelwood, as opposed to Pickering, provided the applicable framework for the teacher's claim. ${ }^{125}$ As of 1989, of course, none of the above cases applying Hazelwood to teachers' in-class speech had yet been decided.

By the time the Fourth Circuit was confronted with the issue in the late 1990s, however, the above cases choosing to apply Hazelwood rather than Pickering had indeed been decided. Thus, the Fourth Circuit was presented with a clear choice between Hazelwood and Pickering - a choice that ultimately prompted the circuit to go en banc.

\footnotetext{
119126 S. Ct. 1951.

${ }^{120}$ For further discussion of the Garcetti case, see infra text accompanying notes 239-245.

${ }^{121}$ Kirkland v. Northside Independent School Dist., 890 F.2d 794 (5th Cir. 1989).

${ }^{122} \mathrm{Id}$. at $795-800$.

${ }^{123}$ Id. at 800 .

${ }^{124} \mathrm{Id}$.

${ }^{125} \mathrm{Id}$.
} 
In the case at issue, Boring v. Buncombe County Board of Education, ${ }^{126}$ a high school drama teacher sued when she was transferred after having the students in her advanced acting class perform a play called "Independence" in a state competition. ${ }^{127}$ The play depicted "the dynamics within a dysfunctional, single-parent family - a divorced mother and three daughters; one a lesbian, another pregnant with an illegitimate child." ${ }^{\prime 28}$ After the district court dismissed her claim, a three-judge panel of the Fourth Circuit reinstated it, concluding that Hazelwood provided "the best means of navigating" her claim. ${ }^{129}$ The court acknowledged that Hazelwood "directly addressed the free speech rights of students, not teachers," but stated that "the rationale that largely animated Hazelwood . . . appears to apply equally well in the context of a teacher's play selection for a schoolsponsored drama production." 130 The court concluded that although legitimate pedagogical reasons might have motivated the school district's decision to discipline the teacher for her speech, none had yet been established on the record. ${ }^{131}$

The Fourth Circuit subsequently heard the case en banc, and in a 7-6 split, ruled that Pickering should instead apply to teachers' classroom speech. ${ }^{132}$ In explaining its decision to apply the Pickering-Connick framework, the majority reasoned that "[t]his is not a case concerning pupil speech, as in Hazelwood, either classroom or otherwise. The case concerns itself exclusively with employee speech, as does Connick."133 The majority further concluded that teachers lacked a First Amendment right "to participate in the makeup of the curriculum of a public high school," reasoning that

\footnotetext{
${ }^{126} 98$ F.3d 1474 (4th Cir. 1996), rev'd, 136 F.3d 364 (4th Cir. 1998) (en banc).

${ }^{127} 98$ F.3d at $1476-77$.

${ }^{128}$ Id. at 1476 .

${ }^{129} \mathrm{Id}$. at 1482 .

${ }^{130} \mathrm{Id}$.

${ }^{131} I d$. at 1479.

${ }^{132}$ Boring, 136 F.3d 364 (4th Cir. 1998) (en banc).

${ }^{133} I d$. at 371 n. 2.
} 
Someone must fix the curriculum of any school, public or private. In the case of a public school, in our opinion, it is far better public policy, absent a valid statutory directive on the subject, that the makeup of the curriculum be entrusted to the local school authorities who are in some sense responsible, rather than to the teachers, who would be responsible only to the judges. ${ }^{134}$

By contrast, the dissent (written by the author of the initial majority opinion) continued to argue that Hazelwood should apply, asserting that the Pickering-Connick framework "did not provide a workable formula for analyzing whether the First Amendment protects a teacher's in class speech .... Her speech is neither ordinary employee workplace speech nor common public debate."

In 2001, the Sixth Circuit threw in its lot with the Fourth and Fifth Circuits, concluding that Pickering should apply to teachers' in-class speech. In the case at issue, Cockrel v. Shelby County School District, ${ }^{136}$ the plaintiff teacher was terminated after, among other things, inviting celebrity Woody Harrelson to come talk to her fifth grade class about the environmental benefits of industrial hemp. ${ }^{137}$ The Sixth Circuit applied Pickering to her First Amendment claim, acknowledging the circuit split but concluding that it saw "no reason to part from Pickering when deciding cases involving a teacher's in-class speech." ${ }^{\prime 38}$ The court went on to rule (unlike the Kirkland and Boring courts) that the teacher's speech had indeed been constitutionally protected, concluding that the

\footnotetext{
${ }^{134} I d$. at 371.

${ }^{135} \mathrm{Id}$. at 378 (Motz, J., dissenting). The dissent also argued that in the alternative, even under the Pickering-Connick framework, the teacher's claim should still go forward. Id. at 378. Somewhat counterintuitively (in light of the dissent's view that Hazelwood should apply and that the case should go forward), the dissent also asserted that Hazelwood is a less speech-protective approach than Pickering. Id. Indeed, the dissent tried to justify the position that Hazelwood should apply precisely on grounds that the Pickering-Connick framework "fails to give school administrators the necessary and appropriate control over a teacher's in-class speech." Id.

${ }^{136} 270$ F.3d 1036 (6th Cir. 2001).

${ }^{137} I d$. at $1042-45$.

${ }^{138}$ Id. at 1055 n. 7.
} 
speech had related to a matter of public concern and that the Pickering balancing weighed in the teacher's favor. ${ }^{139}$

Finally, as noted above, on January 24, 2007 - in the first circuit court decision to address this issue following Garcetti's refinement of the Pickering-Connick frameworkthe Seventh Circuit held in Mayer v. Monroe County Community Schools Corporation ${ }^{140}$ that Pickering and its progeny applied to teachers' classroom speech. On that basis, the Seventh Circuit rejected the plaintiff teacher's First Amendment claim that she had been terminated for telling her students during a classroom discussion of current events that she opposed the war in Iraq, holding that she had been speaking in her capacity as an employee and was therefore unprotected. ${ }^{141}$

The Third, Ninth, and D.C. Circuits have not squarely addressed the issue of how to evaluate the constitutionality of restrictions on teachers' in-class speech, but there are some clues as to how the Third and Ninth Circuits are likely to come out. As noted above, the Third Circuit quite emphatically ruled in Bradley and Edwards that Hazelwood is inapplicable to curricular decisions (which reflect pure government speech and are thus unprotected by the First Amendment), suggesting that the circuit may take a similar approach to teachers' in-class speech. ${ }^{142}$ The signals from the Ninth Circuit, however, have been more mixed. On the one hand, in Downs v. Los Angeles Unified School District, ${ }^{143}$ the Ninth Circuit concluded that a teacher's posting of anti-gay messages on a bulletin board near his classroom was not governed by Hazelwood because

\footnotetext{
${ }^{139} I d$. at 1050-55. The Sixth Circuit recently reaffirmed this approach in Evans-Marshall v. Bd. of Educ. of the Tipp City Exempted Village Sch. Dist., 428 F.3d 223 (6th Cir. 2005).

${ }^{140} 474$ F.3d 477 (7th Cir. 2007).

${ }^{141} I d$. at $478-480$.

${ }^{142}$ This would make Hazelwood inapplicable, and would readily resolve the Pickering inquiry in the government's favor (given the lack of any cognizable First Amendment interest by the teacher).

${ }^{143} 228$ F.3d 1003 (9th Cir. 2000).
} 
the speech at issue was pure government speech. The Downs court stated that the boards were the property of the school district, that "[o]nly school faculty and staff had access to post materials on these boards," and that it was therefore the school district itself speaking through the bulletin boards. Relying in part on the Third Circuit's holdings in Bradley and Edwards, the court concluded that the teacher had "no First Amendment right to speak for the government," and that his First Amendment claim therefore failed. ${ }^{144}$ The following year, however, the Ninth Circuit held that at least as to teachers' instructional speech in the classroom, it would assume arguendo that Hazelwood applied. ${ }^{145}$

Interestingly, in addition to their division over whether Hazelwood or Pickering should apply to teachers' in-class speech, the circuits are not even settled as to which framework provides greater protection for teacher speech in the first place. The Ninth Circuit, in deciding to assume arguendo that Hazelwood should apply to teachers' inclass speech, stated that it was doing so precisely because Hazelwood "appear[ed] to be more speech protective" than Pickering. ${ }^{146}$ By contrast, the Tenth Circuit - as well as the dissenting opinion from the Fourth Circuit in Boring - justified their application of Hazelwood on grounds that Hazelwood provided less protection for teacher speech, and correspondingly greater discretion for school districts, which they deemed appropriate. ${ }^{147}$

\footnotetext{
${ }^{144} I d$. at 1017.

${ }^{145}$ California Teachers Association v. State Board of Educ., 271 F.3d 1141, 1148-49 (9th Cir. 2001) ("We need not resolve this controversy .... to decide the merits of this appeal. Instead, we may assume that the instructional speech [in question] receives some First Amendment protection. Specifically, we will assume that regulations of such speech are subject to the test articulated in Hazelwood.").

${ }^{146} I d$. at 1149 .

${ }^{147}$ See Miles, 944 F.2d at 777 ("Although the Pickering test accounts for the state's interest as an employer, it does not address the significant interests of the state as educator .... The concern addressed in Pickering - the right of an employee to participate as other citizens in debate on public matters - is simply less forceful when considered 'in light of the special characteristics of the school environment."') (quoting Hazelwood, 484 U.S. at 266); Boring, 136 F.3d at 378 (Motz, J., dissenting) (arguing that Hazelwood
} 
This further lack of consensus indicates how deeply the circuits have fractured over this question. It also illustrates the complexity of the issue: none of the above courts explained in detail why they believed that one approach was more speech-protective than the other, and in fact there is some truth to both positions. Pickering provides much more protection when the teacher is speaking as a citizen on a matter of public concern, and much less protection - essentially none at all - in all other circumstances. Hazelwood, by contrast, provides a limited, but consistent, level of protection by generally prohibiting speech restrictions that are not reasonably related to legitimate pedagogical purposes. (Of course, the determination of whether Hazelwood permits viewpoint-based restrictions - the topic that to which I turn in Part III - bears greatly on how speech-protective Hazelwood ends up being.)

The academic commentary, too, is divided. Certain commentators have argued that public school teachers' in-class speech is entitled to significant constitutional protection - particularly given the Supreme Court's broad statements about the importance of academic freedom - and have championed a variety of frameworks to achieve that goal. Gregory Clarick and Emily Holmes Davis, for example, argue that neither Hazelwood nor Pickering are speech-protective enough, and that a Tinker-like standard, under which restrictions on teachers' classroom speech are permitted only upon a showing that the speech caused an actual or potential disruption, should apply. ${ }^{148}$ Karen Daly similarly laments that although the Supreme Court "has spoken approvingly

should apply because "the governmental interest element as set forth in Connick fails to give school administrators the necessary and appropriate control over a teacher's in-class speech. School administrators should be free to specify curriculum and to curtail classroom speech for any legitimate pedagogical reasons. They should not be required to demonstrate that a restriction on in-class speech is necessitated by workplace efficiency or harmony").

${ }^{148}$ Gregory Clarick, supra note 9, at 732; Davis, supra note 9, at 366. 
in dicta of 'academic freedom,' albeit in the context of McCarthy-era statutes," it has not provided any precedent directly on point, and that the lower courts - in turning to either Hazelwood or Pickering to fill the void - have provided insufficient protection for teachers' classroom speech. ${ }^{149}$ She therefore proposes a "mixed procedural-substantive test" - which she refers to as "Hazelwood flipped" - that evaluates teachers' free speech claims on the basis of how much prior notice they received that the speech was prohibited. ${ }^{150}$ In support of this approach, Daly argues that "a system that permits teachers to act as opposing voices within curriculum parameters established by a popularly elected school board minimizes the potential of either actor to distort their educational function into brainwashing." 151

Other commentators, however, argue that whatever the appropriate scope of academic freedom in higher education, the concept of academic freedom is largely inapplicable to the speech of K-12 public school teachers. Todd DeMitchell, for example, directly criticizes Daly's approach on grounds that public school "teachers are hired to speak for the school board[,] thus furthering the school board's message, which is the curriculum." ${ }^{\prime 152}$ Daly's notion of a system that provides some room for teachers to act as opposing voices, DeMitchell argues, thus makes little sense, and would serve only

\footnotetext{
${ }^{149}$ Daly, supra note 9, at 5-16.

${ }^{150} I d$. at 51-56. Specifically, Daly argues that where the teacher received prior notice that her speech was prohibited, she should receive no constitutional protection; conversely, where the teacher received prior administrative approval for the speech, she should receive complete protection. Id. at 54. For the cases that fall in the middle, Daly advocates shifting presumptions: if a reasonable teacher should have been on notice that the speech was prohibited, then the school district should be permitted to discipline the teacher as long as doing so satisfies the Hazelwood test of being reasonably related to legitimate pedagogical concerns; by contrast, if a reasonable educator would have lacked this awareness, then the rebuttable presumption is that the teacher's speech was reasonably related to legitimate pedagogical concerns and therefore constitutionally protected. $I d$. at 54-55.

${ }^{151} I d$. at 45.

${ }^{152}$ DeMitchell, supra note 9, at 475.
} 
to "distance[] the public from their public schools." "153 W. Stuart Stuller similarly likens the notion of academic freedom for K-12 public school teachers to a "fish out of water," stating that in comparison to the role of a university professor, who is charged with the production of scholarship, a public teacher's role is to present course materials and serve as a role model for his students. ${ }^{154}$ Noting that most disputes over such teachers' in-class speech "involve value-based decisions that require a sense of community," Stuller argues that these "questions are best resolved through the democratic process," i.e., the local school board, rather than through First Amendment claims. ${ }^{155}$ In a jointly authored article, Martin Redish and Kevin Finnerty likewise argue that “[a]lthough a teacher's First Amendment right allows him to say what he wishes outside the classroom, the inmates do not run the asylum. If a school board or principal decides that a particular subject is to be taught in a particular way, individual teachers do not have a constitutional right in the classroom to preempt the decisions of their superiors." ${ }^{156}$ A recent Michigan Law Review note similarly argues that teachers' in-class speech should generally receive no First Amendment protection. ${ }^{157}$

\section{C. $\quad$ Speech of Outside Entities}

There is a smaller body of case law (and scant commentary) as to the speech of outside entities - such as recruiters, advertisers, and parents - in school-sponsored contexts, but the trend here is clearly toward the application of Hazelwood. The Ninth

\footnotetext{
${ }^{153}$ Id. at 475-79.

${ }_{154}$ Stuller, supra note 9, at 335-36.

${ }^{155} \mathrm{Id}$.

${ }^{156}$ Redish \& Finnerty, supra note 9, at 67. See also id. at 81-82 ("Whatever the scope of a teacher's First Amendment right to speak outside the four walls of the school or to discuss in school matters unrelated to a curriculum, a teacher has no constitutional right to teach the topics or substance of his choice. ... The classroom, then, is not a public forum where a teacher has a private First Amendment right to communicate..").

157 See generally Donehower, supra note 9.
} 
and Eleventh Circuits have already moved in this direction, as have several district courts.

The Eleventh Circuit was the first to apply Hazelwood to the speech of outside entities in school-sponsored settings, in the 1989 case of Searcey $v$. Harris. ${ }^{158}$ There, the Atlanta Peace Alliance sued the Atlanta School Board over its policy of excluding it from its Career Day program, while permitting military recruiters to participate. ${ }^{159}$ The school board had excluded the Peace Alliance on the basis of its Career Day policy, which stated (among other things) that participants in the program must have "direct knowledge" of the career about which they would speak, must have a "present affiliation" with that career field, and could not criticize or denigrate that career field. ${ }^{160}$ Without any real discussion of whether it mattered that Hazelwood had been a student speech case, the Eleventh Circuit deemed Hazelwood applicable. ${ }^{161}$ It further concluded, as discussed infra, that Hazelwood prohibited viewpoint discrimination, such that it would be unconstitutional for the board to "allow speakers to point out the advantages of a political career but ban any speaker from pointing out the disadvantages of the same career."162

The Ninth Circuit subsequently applied Hazelwood to the speech of outside entities in Planned Parenthood v. Clark County School District, ${ }^{163}$ in which Planned Parenthood sued after a school district refused to accept advertisements that it submitted for publication in the district's high school newspapers, yearbooks, and athletic programs. ${ }^{164}$ Unlike the Eleventh Circuit in Searcey, the Ninth Circuit explicitly

\footnotetext{
${ }^{158} 888$ F.2d 1314 (11th Cir. 1989).

${ }^{159} I d$. at $1315-17$.

${ }^{160} \mathrm{Id}$. at $1317-18$.

${ }^{161} \mathrm{Id}$. at 1319 .

${ }^{162}$ Id. at 1319 \& n. $7,1324-25$.

163 941 F.2d 817 (9th Cir. 1991).

${ }^{164} \mathrm{Id}$. at 820.
} 
addressed whether it was appropriate to extend Hazelwood outside of the student speech context. It answered that question in the affirmative, stating that the Hazelwood Court had specifically "spoke[n] in terms of 'school-sponsored publications, theatrical productions, and other expressive activities." ${ }^{\prime 165}$ The Ninth Circuit further noted that, at the beginning of Hazelwood, the Court had stated that unless the school has opened up its facilities to the general public, "school officials may impose reasonable restrictions on the speech of students, teachers, and other members of the school community." ${ }^{166}$ It thus concluded that "there is no principled distinction between students' constitutional rights and those of Planned Parenthood to access to school-sponsored publications." ${ }^{, 167}$ The Ninth Circuit went on to hold (as had the Eleventh Circuit in Searcey, and as further discussed infra) that Hazelwood prohibited viewpoint discrimination. ${ }^{168}$ Ultimately, however, it ruled in favor of the school district, reasoning that its actions were constitutionally permissible because both pro-choice/birth control-related advertisements and pro-life advertisements had been excluded by district policy. ${ }^{169}$ Similarly, in DiLoreto v. Downey Unified School District, ${ }^{170}$ the Ninth Circuit applied Hazelwood to a plaintiff's claim that his First Amendment rights were violated when a school district refused to post his advertisement displaying the Ten Commandments on the high school baseball field fence. ${ }^{171}$

Recently, a new school fundraising trend has given rise to another type of outside entity speech in the school setting. This trend consists of fund-raisers involving the sale

\footnotetext{
${ }^{165} \mathrm{Id}$. at 827.

${ }^{166} I d$. For further discussion of this portion of Hazelwood, see infra text accompanying notes 217-221.

${ }^{167} I d$.

${ }^{168} I d$. at 829 .

${ }^{169} \mathrm{Id}$.

170196 F.3d 958.

${ }^{171}$ Id. at 962-69.
} 
of bricks or tiles that are going to be placed on some sort of walkway on or near the school, with the idea that purchasers - typically parents - can have a personal message inscribed on the brick or tile. In the past two years, this trend has already given rise to three different district court cases along remarkably similar lines: a parent purchases a brick or tile, submits a religious message to be inscribed (e.g., "[student name,] Jesus Loves You"); the school district refuses the submission, and the parent files a First Amendment claim. ${ }^{172}$ In all three cases, the district courts turned to Hazelwood for guidance, and ultimately held that the school districts' restrictions had reflected unconstitutional viewpoint discrimination. ${ }^{173}$

Two conclusions emerge from an examination of the contexts in which Hazelwood has been applied in the nearly twenty years since it was decided. First, Hazelwood's reach now extends far beyond the student speech context. Second, there is a clear lack of consensus among the circuits as to precisely where the boundaries of its reach should be drawn. Not only are different circuits reaching different conclusions about how broadly Hazelwood should extend, but (as evidenced in the division over teacher speech) they are not even settled as to which rationales point in which directions. These developments have significantly complicated the courts' analysis of whether Hazelwood permits viewpoint-based speech restrictions, the topic to which I now turn.

\footnotetext{
${ }^{172}$ See Kiesinger v. Mexico Academy, 427 F. Supp. 2d 182 (N.D.N.Y. 2006) (involving brick walkway in front of high school); Demmon v. Loudoun Cty. Public Schools, 342 F. Supp. 2d 474 (E.D. Va. 2004) (involving brick "walkway of fame" on high school property); Seidman v. Paradise Valley, 327 F. Supp. 2d 1098 (D. Ariz. 2004) (involving "Tiles for Smiles" program in which parents purchased 4 x 8 tiles to be permanently affixed to interior elementary school walls).

${ }^{173}$ Kiesinger, 427 F. Supp. 2d at 191-195; Demmon, 342 F. Supp. 2d at 488; Seidman, 327 F. Supp. 2d at 1105-1112.
} 


\section{The Split Over Whether Hazelwood Permits Viewpoint-Related Restrictions}

While the circuit division over Hazelwood's reach is significant in its own right, it takes on added importance when viewed in the context of the circuits' division over whether Hazelwood allows viewpoint-related restrictions in addition to content-related restrictions. The Hazelwood Court never explicitly addressed this question, ${ }^{174}$ leaving courts (and commentators) to puzzle over this issue. So far, the Second, Ninth, and Eleventh Circuits have concluded that Hazelwood prohibits viewpoint-based restrictions, while the First and Tenth Circuits have held that it permits them. ${ }^{175}$

Hazelwood itself provides some evidence for both sides of the debate. As described above, in section II.A of its analysis, the Court invoked general public forum principles, stating that

The public schools do not possess all of the attributes of streets, parks, and other traditional public forums .... Hence, school facilities may be deemed to be public forums only if school authorities have 'by policy or practice' opened those facilities for indiscriminate use by the general public, or by some segment of the public such as student organizations. If the facilities have been instead been reserved for other intended purposes, communicative or otherwise, then no public forum has been created, and school officials may impose reasonable restrictions on the speech of students, teachers, and other members of the school community. The government does not create a public forum by inaction or by permitting limited discourse, but only by intentionally opening a nontraditional forum for public discourse. ${ }^{176}$

\footnotetext{
${ }^{174}$ Evidently, the school had conceded that "“control over access' to Spectrum is permissible only if 'the distinctions drawn are viewpoint neutral," "Hazelwood, 484 U.S. at 287 n. 3 (Brennan, J., dissenting), thus moving this issue to the periphery of the case.

${ }^{175}$ The Third and Sixth Circuits also briefly weighed in on the issue, but ultimately retracted those opinions on other grounds. In C.H. v. Oliva, discussed in greater depth infra, a three-judge panel of the Third Circuit initially concluded that Hazelwood permitted viewpoint-based restrictions. 195 F.3d 167, 173 (3d Cir. 1999). The Third Circuit subsequently took the case en banc, at which point it vacated the earlier opinion and resolved the case on other grounds, such that it did not need to resolve the viewpoint discrimination issue. 226 F.3d 198 (3d Cir. 2000). Similarly, in Kincaid v. Gibson, a three-judge panel of the Sixth Circuit initially interpreted Hazelwood as prohibiting viewpoint-based restrictions. 191 F.3d 719, 727 (6th Cir. 1999). The Sixth Circuit then took the case en banc, vacated the earlier decision, and resolved the case on other grounds. 236 F.3d 342 (6th Cir. 2001).

${ }^{176}$ Hazelwood, 484 U.S. at 267 (citing Perry Education Assoc. v. Perry Local Educators' Assoc., 460 U.S. 37, 47 (1983) and Cornelius v. NAACP Legal Defense \& Educational Fund, Inc., 473 U.S. 788, 802 (1985)).
} 
The Hazelwood Court went on to conclude that, because the Spectrum was "part of the educational curriculum and a "regular classroom activity"' subject to considerable oversight by the journalism teacher and ultimately the school principal, it constituted a nonpublic forum. ${ }^{177}$ The Court thus concluded, citing its previous seminal decisions in Perry and Cornelius (which outlined the legal framework for First Amendment cases involving nonpublic fora) that "school officials were entitled to regulate the contents of Spectrum in any reasonable manner."

What the Hazelwood Court omitted, however, was that Perry and Cornelius had not only held that restrictions in nonpublic fora had to be reasonable, but had also stated that such restrictions must be viewpoint-neutral. ${ }^{179}$ In only discussing the need for reasonableness, then, the Hazelwood Court left unclear whether the viewpoint neutrality requirement still applied to the school district's restrictions on the Spectrum. While Hazelwood's invocation of Perry and Cornelius in section II.A arguably points in the direction of maintaining the viewpoint neutrality requirement, subsequent parts of Hazelwood - such as its subsequent statement in section II.B that a school must "retain the authority to refuse to sponsor student speech that might reasonably perceived to advocate drug or alcohol use, irresponsible sex, or conduct otherwise inconsistent with 'the shared values of a civilized social order"',180 - point the other way.

\footnotetext{
${ }^{177}$ Hazelwood, 484 U.S. at 568-70.

${ }^{178} \mathrm{Id}$. at 570.

${ }^{179}$ Cornelius, 473 U.S. at 806 ("Control over access to a nonpublic forum can be based on subject matter and speaker identity so long as the distinctions drawn are reasonable in light of the purpose served by the forum and are viewpoint neutral.") (citing Perry, 460 U.S. at 49)).

${ }^{180}$ Hazelwood, 484 U.S. at 272.
} 
The Second, Ninth, and Eleventh Circuits have interpreted Hazelwood as implicitly maintaining the viewpoint neutrality requirement. "The prohibition against viewpoint discrimination is firmly embedded in first amendment analysis," the Eleventh Circuit reasoned in Searcey, the first circuit court decision addressing this issue. ${ }^{181}$ "Without more explicit direction, we will continue to require school officials to make decisions relating to speech that are viewpoint neutral." ${ }^{\text {182 }}$ Similarly, in Planned Parenthood, the Ninth Circuit simply cited Cornelius and Perry in concluding that Hazelwood required viewpoint neutrality. ${ }^{183}$ Most recently, in late 2005, in Peck v. Baldwinsville Central School District, ${ }^{184}$ the Second Circuit likewise relied on Cornelius and Perry in holding that Hazelwood did not permit viewpoint-based restrictions, noting that Hazelwood had itself made reference to Cornelius and Perry, and stating that "we are reluctant to conclude that the Supreme Court would, without discussion and indeed totally sub silentio, overrule Cornelius and Perry - even in the limited context of schoolsponsored student speech." ${ }^{185}$

Commentators asserting that Hazelwood should be read as requiring viewpoint neutrality have generally argued along similar lines. Katie Hammett, for example, argues that "[g]iven the clear public forum standards developed and the great importance of the First Amendment protection of free speech, it seems much more likely that if the majority in Hazelwood meant to create a new category in the public forum and not require viewpoint-neutrality, as is required in all other categories, the Court would have

\footnotetext{
${ }^{181}$ Searcey, 888 F.2d at 1325.

${ }^{182} \mathrm{Id}$.

${ }^{183}$ Planned Parenthood, 941 F.2d at 829.

${ }^{184} 426$ F.3d 617 (2d Cir. 2005).

${ }^{185} \mathrm{Id}$. at $632-33$.
} 
explicitly stated that it was doing so."186 Denise Daugherty similarly argues that "[i]n the absence of clear instruction from the Supreme Court to abandon the viewpoint neutral requirement on restrictions of free speech, the circuit courts should not discard the requirement on their own.",187

The First and Tenth Circuits, by contrast, have both concluded that Hazelwood permits viewpoint discrimination. The First Circuit reached that conclusion without much analysis in Ward, a teacher speech case, simply stating that "while citing Perry, [Hazelwood] did not require that school regulation of school-sponsored speech be viewpoint neutral."188

The Tenth Circuit analyzed the viewpoint discrimination issue in more depth in Fleming v. Jefferson County School District, ${ }^{189}$ a case involving tiles that were painted by students and their families in the aftermath of the April 1999 Columbine High School massacre. Columbine had implemented a tile-painting project designed to reintroduce students to the school, but had prohibited tiles that included "religious symbols, the date of the shooting, or anything obscene or offensive," and on that basis refused to hang certain tiles (which included, inter alia, crosses, gang graffiti, the date 4-20, a skull dripping with blood, and a Jewish star) in school hallways. ${ }^{190}$ Analyzing the plaintiffs' claim that the school's refusal to hang their tiles violated their free speech rights, the Tenth Circuit concluded that Hazelwood did not require viewpoint neutrality, reasoning that the "Court's specific reasons supporting greater control over school-sponsored speech, such as determining the appropriateness of the message, the sensitivity of the

\footnotetext{
${ }^{186}$ Hammett, supra note 9, at 405.

${ }^{187}$ Daugherty, supra note 9, at 1083.

${ }^{188}$ Ward v. Hickey, 996 F.2d 448, 454 (1st Cir. 1993).

189298 F.3d 918 (10th Cir. 2002).

${ }^{190}$ Id. at $921-22$.
} 
issue, and with which messages a school chooses to associate itself, often will turn on viewpoint-based judgments. ... No doubt the school could promote student speech advocating against drug use, without being obligated to sponsor speech with the opposing viewpoint." ${ }^{, 191}$ Janna Annest similarly argues that Hazelwood implies the permissibility of viewpoint-based restrictions in school-sponsored contexts, arguing that "[i]f the Court intended to impose standard nonpublic forum strictures on public schools, the principal's actions would have been analyzed for evidence of viewpoint-neutrality instead of simply for reasonableness. ${ }^{192}$

Thus, as with the circuit split over Hazelwood's reach, here too courts and commentators are divided. But while much attention has been devoted to analyzing each of these splits as distinct phenomena, there has been very little examination of whether the two splits are related. In fact, as I argue below, the two splits are connected in an important way that helps to shed light on both issues.

\section{The Connective Thread: Linking The Two Splits}

How does the circuit split over Hazelwood's reach connect to the circuit split over whether Hazelwood permits viewpoint-based restrictions? My thesis is straightforward: when evaluating whether Hazelwood permits viewpoint discrimination, courts have been influenced (perhaps without even realizing it) by the context in which they are applying it. As such, the extension of Hazelwood to contexts beyond school-sponsored student speech has directly contributed to the confusion and conflict over whether Hazelwood should be interpreted as permitting viewpoint discrimination.

191 Id. at 928.

${ }^{192}$ Annest, supra note 9, at 1249. 
Indeed, out of the five circuits that have conclusively reached the Hazelwood viewpoint discrimination issue, three of them did so in cases that did not even involve student speech. As noted above, the First Circuit first reached the issue in Ward, which was a teacher classroom speech case. The Ninth and Eleventh Circuits, meanwhile, both reached the issue in outside entity speech cases (respectively, Planned Parenthood and Searcey). It is not surprising, therefore, that the First Circuit readily concluded that Hazelwood permitted viewpoint-based restrictions, while the Ninth and Eleventh Circuit came down on the other side. The question of whether school districts can implement restrictions as to the viewpoints that a teacher expresses to her students in the classroom implicates very different concerns than the question of whether school districts can maintain viewpoint-based restrictions once they open school-sponsored settings up to speech by outside entities. In short, once Hazelwood is interpreted as applying to the speech of students, teachers, and outside entities, it is not possible to reach a uniform, workable answer to the viewpoint discrimination question.

The notion that a school district cannot impose viewpoint-based restrictions as to what its teachers say to students in the classroom is deeply problematic. It would suggest, for instance, that if the curriculum included a unit on slavery, it would violate teachers' First Amendment rights to permit them to express anti-slavery views while prohibiting them from expressing pro-slavery views. Teachers sharing anti-democracy views with their students in the context of a government class would be similarly protected. ${ }^{193}$ While courts would still likely be able to impose certain constraints on

\footnotetext{
${ }^{193}$ Cf. Stuller, supra note 9, at 341 (arguing that "the normal operations of schools would be rife with First Amendment horror shows if only the First Amendment applied. Teachers are routinely required to have their lesson plans approved in advance: prior restraints. They are often called upon to teach from a text with which they have a measure of disagreement: coerced speech. And, of course, viewpoint
} 
teacher autonomy - for example, the Establishment Clause would limit teachers' ability to engage in religious speech - a ruling that Hazelwood applies to teachers' in-class speech and prohibits all viewpoint-based speech restrictions would clearly transfer tremendous authority from democratically-elected school boards to individual teachers. Indeed, it would largely undermine school boards' ability to shape and control what students in the district were learning in their classrooms.

Once a court concludes that Hazelwood applies to teacher speech, therefore, it is naturally propelled toward the conclusion that Hazelwood permits viewpoint-based restrictions, as was the First Circuit in Ward. Conversely, and as discussed in more detail below, no circuit holding viewpoint discrimination impermissible under Hazelwood has so held in a case involving the application of Hazelwood to teachers' classroom speech.. Relatedly, it is noteworthy that other than the First Circuit, the other circuit having explicitly held viewpoint-related restrictions permissible - the Tenth Circuit - is also one that, as discussed above, had already been in the forefront of applying Hazelwood to teachers' classroom speech and even curricular selection. Had the Tenth Circuit held in Fleming that viewpoint discrimination was impermissible under Hazelwood, its precedents, taken together, would have suggested that school officials could not regulate the viewpoints that teachers communicated to their students in class.

By contrast, of the three circuits concluding that viewpoint discrimination is impermissible under Hazelwood (the Second, Ninth, and Eleventh), two reached that conclusion in cases involving the speech of outside entities. As noted above, the Ninth Circuit decided that Hazelwood forbade viewpoint discrimination when evaluating 
Planned Parenthood's right to advertise in school publications, and the Eleventh Circuit reached that conclusion when evaluating peace activists' right to participate alongside military recruiters in a high school career fair. Just as it makes sense that the First Circuit concluded that Hazelwood permitted viewpoint-based restrictions when it viewed the issue through the lens of teacher speech, so too does it follow that the Ninth and Eleventh Circuits held that Hazelwood forbade viewpoint-based restrictions when they were introduced to the question in the context of speech by outside entities. Unlike teachers' classroom speech - which school districts hire teachers to engage in, and which is at the very center of schools' educational and inculcative functions - the speech of outside entities such as recruiters and advertisers is far more analogous to the speech that generally triggers basic public forum analysis, under which viewpoint-based restrictions even in nonpublic fora are unconstitutional.

It is ironic that although Hazelwood was a student speech case, much of the courts' analysis over whether it allows viewpoint discrimination has arisen in other factually distinct contexts. It is also unfortunate. Courts that have broadly extended Hazelwood to a variety of school-sponsored speech contexts, and are reaching the Hazelwood viewpoint discrimination issue in whichever context it arises first, run the risk of unnecessarily boxing themselves in for future cases.

The Ninth and Eleventh Circuits have already been faced with this predicament. The Ninth Circuit confronted it in Downs v. Los Angeles United School District, ${ }^{194}$ a 2000 case in which a high school teacher who objected to the school's recognition of "Gay and Lesbian Awareness Month" created his own bulletin board entitled "Testing

${ }^{194} 228$ F.3d 1003 (9th Cir. 2000). 
Tolerance." 195 This bulletin board featured a portion of the Declaration of Independence, excerpts from newspaper articles (including one indicating that $60 \%$ of Americans considered homosexuality immoral), and a Bible quote condemning homosexuality. ${ }^{196}$ His bulletin board thus stood as a direct response to the bulletin boards that his colleagues - whose boards depicted rainbow flags, lists of famous gays and lesbians in history, articles about domestic partnership benefits, and the like - had created. ${ }^{197}$ When district officials ordered the materials removed, the teacher brought a First Amendment claim, and contended on appeal that even if Hazelwood applied to his speech (as the district court had held in dismissing his claim), Hazelwood required viewpoint neutrality. ${ }^{198}$ In support of this position, the teacher was able to invoke Planned Parenthood, in which the Ninth Circuit had held that Hazelwood was broadly applicable in school-sponsored speech contexts and that it forbade viewpoint discrimination. ${ }^{199}$

The Downs Court thus found itself painted into a corner: it quite evidently felt that the school district should be permitted to restrict this sort of teacher speech, but the viewpoint neutrality requirement previously adopted by the Ninth Circuit in Planned Parenthood made it difficult to reach that outcome. After all, the school was censoring a bulletin board expressing negative messages about homosexuality while permitting bulletin boards expressing the contrary viewpoint to remain. The court ended up taking a circuitous route to arrive at its desired result. It held that the teacher's speech on the bulletin board was not in fact teacher speech at all, but rather pure government speech,

\footnotetext{
${ }^{195} \mathrm{Id}$. at 1006 .

${ }^{196} I d$. at $1006-07$.

${ }^{197}$ Id. at 1006 .

${ }^{198}$ Id. at $1005,1008$.

${ }^{199}$ See supra text accompanying notes 163-69.
} 
because the principal retained authority over all of the school bulletin boards. ${ }^{200}$ As such, the court reasoned, Planned Parenthood and its viewpoint neutrality requirement were inapplicable. $^{201}$

This solution, while initially appealing, fails to hold up under examination. The actual speech in question was not pure government speech: it did not reflect the views of the school district, and indeed was directed at opposing the school's decision to recognize Gay and Lesbian Awareness Month. That the principal retained authority over the bulletin board upon which the teacher had posted this dissenting speech did not transform that speech into pure school speech any more than the Hazelwood East High School principal's authority to censor the Spectrum rendered that newspaper pure government speech. Just as the Hazelwood Court deemed the Spectrum "school-sponsored" speech (rather than pure government speech, a possibility that the Hazelwood Court did not even consider), so too did the Downs teacher's speech fall into that category. But because that conclusion would have forced the Ninth Circuit to apply Planned Parenthood - which it made clear that it did not want to $\mathrm{do}^{202}-$ it adopted the logically problematic approach of deeming the teacher's speech to be government speech and distinguishing Planned Parenthood on that basis. The constraints that pushed the Downs court toward that approach are evident, but a more intellectually honest solution would have been to directly revisit Planned Parenthood's broad holding that Hazelwood was applicable

\footnotetext{
${ }^{200} I d$. at $1011-12$.

$201 \mathrm{Id}$. at 1011.

${ }^{202}$ Id. at 1010-11 ("Despite the absence of express 'viewpoint neutrality' discussion anywhere in Hazelwood, the Planned Parenthood court incorporated 'viewpoint neutrality' analysis into nonpublic forum, school-sponsored speech cases in our Circuit. Thus, were Downs's case a case of school-sponsored or imprimatur speech in a nonpublic forum - as the district court concluded - we would necessarily be compelled by Planned Parenthood to review [the school district's] actions through a viewpoint neutrality microscope.").
} 
beyond school-sponsored student speech and generally prohibited viewpoint discrimination.

The Eleventh Circuit found itself similarly constrained when it had to decide Bannon v. School District of Palm Beach County. ${ }^{203}$ There, a high school undergoing a long-term remodeling decided to invite its students to paint murals on the large plywood panels that appeared throughout the school's exterior and interior hallways. The only instruction given to the students was that their artwork "could not be profane or offensive to anyone. ${ }^{204}$ One student proceeded to paint three murals that featured religious language (such as “God Loves You. What Part of Thou Shalt Not Didn't You Understand? God.") and symbols (such as crucifixes). ${ }^{205}$ The murals quickly led to commotion and media attention, and the faculty advisor ordered the student to paint over the religious portions of her murals. ${ }^{206}$ The student, in turn, brought a First Amendment claim, arguing that this amounted to viewpoint discrimination, which the Eleventh Circuit had already held in Searcey (again, a case involving outside entity speech) was impermissible under Hazelwood. ${ }^{207}$

A recent string of Supreme Court cases, culminating in Good News Club v. Milford Central School, ${ }^{208}$ supported the student's argument that the exclusion of her religiously-themed murals constituted viewpoint discrimination. ${ }^{209}$ The Bannon majority

\footnotetext{
${ }^{203} 387$ F.3d 1208 (11th Cir. 2004).

${ }^{204} \mathrm{Id}$. at 1210 .

${ }^{205} \mathrm{Id}$. at 1211 .

${ }^{206} \mathrm{Id}$.

${ }^{207} \mathrm{Id}$. at $1211-12$.

208533 U.S. 98 (2001).

${ }^{209}$ In Good News, a school district had established a community use policy whereby the school building could be used after hours by district residents for "instruction in any branch of education, learning or the arts," and could also be used for "social,, civic and recreational meetings and entertainment events, and other uses pertaining to the welfare of the community." Id. at 102. The policy prohibited, however, the use of the building for religious purposes. Id. at 103. On that basis, the district refused to allow the Good
} 
opinion, however, did not even mention Good News. Instead, referring only to the Supreme Court cases that had preceded Good News (which were less directly on point), it held rather summarily that "the school did not engage in viewpoint discrimination, but rather censored the murals on the basis of their content ... . [t]hese are obviously inherently religious messages, which cannot be recast as the discussion of secular topics from a religious perspective." ${ }^{210}$ Having essentially assumed away the viewpoint discrimination issue, the majority then easily held that the restriction satisfied Hazelwood because it was reasonably related to the legitimate pedagogical concern of reducing the disruption caused by the murals. ${ }^{211}$

The Bannon concurrence, by contrast, acknowledged that under the relevant Supreme Court precedents, the school district's actions reflected viewpoint discrimination, which the Eleventh Circuit's Searcey decision had previously interpreted Hazelwood as prohibiting. ${ }^{212}$ The concurrence concluded, however, that Searcey could be distinguished because Searcey had involved outside entity speech, while this case involved student speech. ${ }^{213}$ "Searcey merely stands for the proposition that when a school has opened itself to outside speakers for some school-sponsored function, such as career day, it may not discriminate against the outside speakers' viewpoints," the

\footnotetext{
News Club - whose activities included prayer and proselytization - to use the school building after hours. The Supreme Court held that this amounted to viewpoint discrimination, on grounds that the Club merely sought "to address a subject otherwise permitted under the rule, the teaching of morals and character, from a religious standpoint." Id. at 109-110. It further held that viewpoint discrimination was impermissible in a limited public forum (which both sides agreed had been created by the district's actions), and that the district's actions were therefore unconstitutional. Id. at 111-12. Because the situation in Good News involved a limited public forum rather than a nonpublic forum, Hazelwood was inapplicable.

${ }^{210} I d$. at 1216.

${ }^{211}$ Id. at 1217.

${ }^{212}$ Id. at 1217 (Black, $J$., concurring).

${ }^{213}$ Id. at $1218-19$.
} 
concurrence argued. ${ }^{214}$ By contrast, the concurrence continued, Hazelwood could still be read as permitting viewpoint-based restrictions against school-sponsored student speech, particularly given the portions of Hazelwood regarding student speech that might be perceived as advocating drug use, alcohol use, or irresponsible sex. ${ }^{215}$ The concurrence thus agreed that the school district's speech restriction had been permissible, but followed a different route in getting there. ${ }^{216}$

Downs and Bannon illustrate the problematic intersection between the broad extension of Hazelwood and the viewpoint discrimination issue. School-sponsored speech encompasses a broad range, and the interests implicated by teachers' classroom speech, outside entity speech, and student speech are significantly different. A one-sizefits-all approach to all school-sponsored speech, therefore, is destined for failure. The Bannon concurrence does offer one possible solution to the problem: holding that Hazelwood's "reasonably related to legitimate pedagogical concerns" standard applies across-the-board to school-sponsored speech, but interpreting this standard as permitting viewpoint-based restrictions in some contexts while not in others.

The better approach, however, is to return to Hazelwood's core as a student speech case, and to limit its applicability to that setting. Of course, courts often apply precedents to factually distinct settings - broadening, contracting, and otherwise modifying them along the way. In Hazelwood's case, however, this extension into factually distinct contexts has been ill-advised. A close examination of Hazelwood

\footnotetext{
${ }^{214} \mathrm{Id}$. at 1218 .

${ }^{215} \mathrm{Id}$.

${ }^{216}$ Neither the majority nor the concurrence addressed the separate question of whether the murals' presence would have created an Establishment Clause problem. Having ruled that the restriction on the murals did not violate the First Amendment in the first place, they did not need to proceed to that aspect of the school district's defense.
} 
makes clear that it did not simply arise in a student speech context, but that its entire rationale and approach are uniquely suited to student speech. Furthermore, as discussed below, other existing legal frameworks are far more appropriate for the other categories of school-sponsored speech to which Hazelwood has been applied, and there is no reason to interpret Hazelwood as supplanting those frameworks.

The notion that Hazelwood should apply to all school-sponsored speech seems to stem from the Hazelwood Court's initial broad statement that when school facilities have been reserved for specified intended purposes, "no public forum has been created, and school officials may impose reasonable restrictions on the speech of students, teachers, and other members of the school community."217 Indeed, the Ninth Circuit explicitly relied on this statement in rejecting Planned Parenthood's argument that Hazelwood applied only to student speech. ${ }^{218}$ This, however, reflects a misreading of Hazelwood. That initial statement occurred in Section II.A of the opinion, where the Court essentially summarized its public forum jurisprudence and reiterated the reasonableness test that applies to nonpublic fora. ${ }^{219}$ The next part of the opinion - Section II.B - reflects the Court's attempt to flesh out what reasonableness meant in the particular context of school-sponsored student speech, which was the particular issue raised by the facts in Hazelwood. $^{220}$ It was specifically in that latter, student-focused portion that the Court articulated the "reasonable relation to a legitimate pedagogical concern" standard. ${ }^{221}$

\footnotetext{
${ }^{217}$ Hazelwood, 484 U.S. at 267.

218 Planned Parenthood, 941 F.2d at 827.

${ }^{219}$ Hazelwood, 484 U.S. at 267-70.

${ }^{220} \mathrm{Id}$. at $270-73$.

${ }^{221} I d$. at 273. Karen Daly has reached the same conclusion, noting that the "structure of the [Hazelwood] opinion argues for limitation of the 'reasonably related pedagogical concerns' standard to student speech." Daly, supra note 9, at 12.
} 
In addition to the distinct section headings, two other pieces of textual evidence indicate that this standard was formulated specifically for the student speech context. First, almost every sentence in this portion of the discussion refers explicitly to "student expression" or "student speech" - including, most importantly, the very sentence setting forth the "reasonable relation to a legitimate pedagogical concern" standard. ${ }^{222}$ Second, several of the interests that the Hazelwood Court identified as giving rise to legitimate pedagogical concerns indicate that the Hazelwood Court largely had student speech in mind. Although some of the interests mentioned by the Court are equally applicable to speakers and listeners (such as restricting speech that is biased, prejudiced, vulgar, profane, or inappropriate for the students' level of maturity), others bespeak a particular emphasis on teaching the speaker a lesson. ${ }^{223}$

For example, one pedagogical interest cited by the Hazelwood Court was a school's need to ensure that participants in school-sponsored activities "learn whatever lessons the activity is designed to teach," along with its related need to disapprove of "ungrammatical, poorly written, [or] inadequately researched" speech. ${ }^{224}$ Indeed, the Court later found that the Hazelwood East principal's censorship had been reasonable precisely because he could have concluded that the students writing these articles had

\footnotetext{
${ }^{222}$ In the very first sentence of Section II.B, the Court framed the question as "whether the First Amendment requires a school affirmatively to promote particular student speech." Hazelwood, 484 U.S. at 270. It went on to state that "educators are entitled to exercise greater control over this ... form of student expression," that "[a] school must be able to set high standards for the student speech that is disseminated under its auspices ... and may refuse to disseminate student speech that does not meet those standards," that "a school must be able to take into account the emotional maturity of the intended audience in determining whether to disseminate student speech on potentially sensitive topics," that "a school must also retain the authority to refuse to sponsor student speech that might reasonably be perceived to advocate drug or alcohol use," and, finally, that "educators do not offend the First Amendment by exercising editorial control over the style and content of student speech in school-sponsored expressive activities so long as their actions are reasonably related to legitimate pedagogical concerns." Id. at 271-73.

${ }^{223}$ See Buss, School Newspapers, supra note 9, at 520-21 (noting that "the Court in Hazelwood was not very clear in delineating whether Spectrum was a curricular device for teaching its readers or its writers").

${ }^{224}$ Hazelwood, 484 U.S. at 271-72.
} 
failed to master relevant portions of the Journalism II curriculum. ${ }^{225}$ This rationale makes sense only in the context of student speech. As Karen Daly writes, "school administrators ... have no stake in ensuring teachers learn whatever lessons the activity is ... designed to teach."226 The same is, of course, true for outside entities. By the same token, school officials have no real interest in improving the research and writing skills of teachers or outside entities; here, too, a legitimate pedagogical concern arises only if the speaker is a student.

Similarly, the Hazelwood Court also identified the interest that schools have in "awakening . . child[ren] to cultural values" and "preparing them for professional training," and explained that in order to fulfill this role, schools must retain the authority to restrict "student speech that might reasonably be perceived to advocate conduct ... inconsistent with the shared values of a civilized social order." ${ }^{, 227}$ Here, too, the Court appears to have been particularly concerned with teaching student speakers a lesson namely, how to conduct themselves appropriately in public settings so that they would be prepared for successful and productive adult lives.

The broad spirit of Hazelwood, in addition to its text, also counsels its limitation to the student speech setting. The Tinker/Hazelwood division of the student speech universe - whereby students have quite broad freedom to express their personal views on school premises, but are subject to greater oversight when they do so within the context of school-sponsored activities - strikes a balance reflecting the unique relationship between students and their schools. On the one hand, school serves as a microcosm of society for K-12 students. School is their primary opportunity to meet and communicate

${ }^{225}$ Id. at 276.

${ }^{226}$ Daly, supra note 9, at 13.

${ }^{227}$ Hazelwood, 484 U.S. at 272. 
with each other, and it is there that they take on positions of leadership among their peer community in formal and informal ways. Indeed, as Tinker itself noted, among the activities to which schools are dedicated is "personal intercommunication among the students. ${ }^{228}$ At the same time, school is a crucial societal mechanism for educating and inculcating them in cultural values and mores. The Tinker/Hazelwood regime responds to that duality by roughly aligning the degree of school authority over student speech with the level of school sponsorship (and thus apparent approval) of that speech. ${ }^{229}$

Neither teachers nor outside entities stand in that same relationship toward schools, and other legal doctrines provide better frameworks for assessing the constitutionality of school restrictions as to their speech. The relationship between schools and teachers is, at bottom, an employer/employee relationship. As W. Stuart Stuller writes, "[t]eaching is an occupation effected through speech." 230 Teachers speak to students in the classroom because that is what they are hired and paid to do, and such in-class speech occurs in their role as adult authority figures. When schools impose restrictions as to teachers' classroom speech, those restrictions are not there to achieve the Hazelwood interests of improving their grammar, instructing them in social norms, or preparing them for successful careers. Rather, such restrictions - regardless of whether they are well- or ill-advised in particular cases - reflect a supervisory attempt to control how teachers are performing their job of conveying information to students.

\footnotetext{
${ }^{228}$ Tinker, 393 U.S. at 512.

${ }^{229}$ As discussed below in a Section V, I believe that this alignment can be beneficially tightened through a sliding-scale approach to Hazelwood. Where the perception of school imprimatur is likely to be at its highest, schools should have more freedom to dissociate themselves from the speech in question. See infra text accompanying notes 259-305.

${ }^{230}$ Stuller, supra note 9 , at 341 .
} 
It follows that the Pickering framework, as further refined by Connick and Garcetti, that generally covers public employees provides the best fit for assessing school districts' restrictions on the classroom speech of public school teachers. It is already well established that this framework applies to teacher speech outside of the classroom. As described above, Pickering itself involved a public school teacher's letter to the editor, and several other Supreme Court cases have also applied Pickering to the speech of public school teachers. Givhan v. Western Line Consolidated School District, ${ }^{231}$ for example, involved a teacher's complaint to the principal about the school's racially discriminatory practices, ${ }^{232}$ and Mt. Healthy City School District v. Doyle ${ }^{233}$ involved a teacher's call to a local radio station. ${ }^{234}$

The courts deeming Hazelwood rather than Pickering applicable to teachers' inclass speech have nonetheless concluded (either explicitly or implicitly) that the classroom context somehow renders Pickering inapplicable. ${ }^{235}$ The Fourth Circuit's initial Boring opinion, for example, stated that the Pickering-Connick "'public concern' analysis simply does not provide a very useful tool when analyzing a teacher's classroom speech [because] the essence of a teacher's role in the classroom, and therefore as an employee, is to discuss with students issues of public concern."236 Several commentators similarly argue that the classroom environment is so unique that Pickering cannot apply to teacher speech that occurs within it. Karen Daly, for instance, writes that the "the

\footnotetext{
${ }^{231} 439$ U.S. 410 (1979).

${ }^{232}$ Id. at $412-13$.

233429 U.S. 274 (1977).

${ }^{234} \mathrm{Id}$. at 282.

${ }^{235}$ The dissent from the Boring en banc opinion, for example, argued that Pickering "did not provide a workable formula for analyzing whether the First Amendment protects a teacher's in class speech .... Her speech is neither ordinary employee workplace speech nor common public debate." Boring $v$. The Buncome Cty. Bd. of Educ., 136 F.3d 364, 378 (4th Cir. 1998) (en banc) (Motz, J., dissenting). ${ }^{236}$ Boring v. The Buncombe Cty. Bd. of Educ., 98 F.3d 1474, 1479-80 (4th Cir. 1996).
} 
Pickering line of cases fails to account for the unique job requirements of public school teachers," who "are expected to engage in semi-public speech on a variety of topics.",237 Gregory Clarick likewise argues that "the distinction between speech related to issues of public concern and speech internal to an employee's workplace does not take into account the function and unique atmosphere of teaching." 238

Given that the entire Pickering-Connick framework centers on a threshold assessment of the capacity in which the public employee has spoken, however, it is difficult to see why it cannot encompass the classroom speech context. The fact that a public school teacher's speech has been uttered in the classroom to students - rather than to a radio station, newspaper, or principal - may ultimately lead to a different outcome under Pickering. But that should not utterly remove the case from Pickering's domain.

The Supreme Court's 2006 Garcetti decision confirms this view. There, a deputy district attorney brought a First Amendment claim after being retaliated against for writing a memo to his supervisors in which he concluded that an affidavit used to obtain a search warrant had contained serious misrepresentations, and that the resulting criminal case should therefore be dismissed. ${ }^{239}$ Garcetti thus required the Court to clarify an important question about the public employee framework that had been developed in Pickering and Connick. As described above, the threshold inquiry under that framework is whether the employee was speaking as a citizen on a matter of public concern. Here, the plaintiff did not dispute that he had prepared the memo pursuant to his employment duties as a prosecutor, but argued that his speech nonetheless satisfied the threshold

${ }^{237}$ Daly, supra note 9, at 10.

${ }^{238}$ Clarick, supra note 9, at 702.

${ }^{239} 126$ S. Ct. at $1955-56$. 
because it related to a matter of public concern (governmental misconduct). ${ }^{240}$ The Supreme Court, however, held that his speech did not meet the threshold, emphasizing that the central inquiry under Pickering-Connick was whether the speech had been uttered in the plaintiff's capacity as an employee. The Court wrote:

We hold that when public employees make statements pursuant to their official duties, the employees are not speaking as citizens for First Amendment purposes, and the Constitution does not insulate their communications from employer discipline.... When he went to work and performed the tasks he was paid to perform, Ceballos acted as a government employee. The fact that his duties sometimes required him to speak or write does not mean his supervisors were prohibited from evaluating his performance. ${ }^{241}$

Garcetti, despite its occurrence outside of the public school context, is instructive. The deputy district attorney's memo was essentially a hybrid of employee speech and speech on a matter of public concern - the same characteristic of teachers' classroom speech that some courts and commentators have identified as making Pickering useless. But the Garcetti Court did not hesitate to apply the Pickering-Connick framework to the deputy district attorney's speech. Indeed, no part of the opinion - including the dissents - even suggested that the hybrid nature of this speech somehow rendered Pickering altogether inapplicable. Their only disagreement related to the case's outcome under Pickering. This calls into question any notion that Pickering is not also capacious enough to include teachers' classroom speech. Indeed, as described above, in the first post-Garcetti circuit court case involving a teacher's classroom speech-Mayer v. Monroe County Community School Corporation ${ }^{242}$ - the Seventh Circuit applied Pickering (as refined by Garcetti) without even acknowledging its previous invocation of Hazelwood.

${ }^{240} I d$. at 1959-60.

${ }^{241}$ Id. at 1960.

242474 F.3d 477 (7th Cir. 2007). 
Of course, Garcetti also suggests that public school teachers' classroom speech would likely not get past the threshold for First Amendment protection. Just like the deputy district attorney in Garcetti, when public school teachers speak in the classroom, they are acting as government employees, regardless of whether that speech also happens to touch on a matter of public concern. Indeed, in his dissent, Justice Souter flagged this very issue. He noted that the Garcetti majority's interpretation of Pickering was "spacious enough to include even the teaching of a public university professor," adding that "I have to hope that today's majority does not mean to imperil First Amendment protection of academic freedom in public colleges and universities, whose teachers necessarily speak and write 'pursuant to official duties." ${ }^{243}$ The majority, in turn, explicitly responded that "Justice Souter suggests today's decision may have important ramifications for academic freedom, at least as a constitutional value. There is some argument that expression related to academic freedom or classroom instruction implicates additional constitutional interests that are not fully accounted for by this Court's customary employee-speech jurisprudence. We need not, and for that reason do not, decide whether the analysis we conduct today would apply in the same manner in a case involving speech related to scholarship or teaching." 244

It is true that the Garcetti majority's language (unlike Justice Souter's dissent) referred generally to "academic freedom," and did not explicitly limit itself to speech by public college and university professors. It seems unlikely, however, that the majority intended to carve out a broader swath than Justice Souter had himself identified as being in jeopardy. Not only was the majority responding directly to Justice Souter, but the

\footnotetext{
${ }^{243}$ Garcetti, 126 S. Ct. at 1969-70 (Souter, J., dissenting).

${ }^{244}$ Id. at 1962.
} 
concept of academic freedom is far more established at the university level than at the K-

12 public school level, where school boards bear ultimate responsibility for curricular and

policy decisions. As the Seventh Circuit concluded in Mayer:

$\mathrm{K}-12$ public "[e]ducation is compulsory, and children must attend public schools unless their parents are willing to incur the cost of private education or the considerable time commitment of home schooling. Children who attend school because they must ought not be subject to teachers' idiosyncratic perspectives. Majority rule about what subjects and viewpoints will be expressed in the classroom has the potential to turn into indoctrination ... But if indoctrination is likely, the power should be reposed in someone the people can vote out of office, rather than tenured teachers. At least the board's views can be debated openly, and the people may choose to elect persons committed to neutrality on contentious issues. $^{245}$

That said, it remains to be seen how the Supreme Court will ultimately apply the Pickering-Connick-Garcetti framework to the professorial context, and it is at least plausible that the Court will do so in a way that provides some constitutional protection for the classroom speech of K-12 public school teachers. My purpose is not to speculate about whether and how this might occur, but simply to emphasize that any First Amendment protection for teachers' classroom speech should stem from that public employment-based framework, rather than from Hazelwood. ${ }^{246}$ Trying to fit the square

\footnotetext{
${ }^{245}$ Mayer, 474 F.3d at 479-80.

${ }^{246}$ It also should be noted that, even if the Supreme Court ultimately concludes that teachers lack First Amendment protection for their classroom speech, that will not leave them wholly without job protection. Tenured teachers possess extensive job security. Circuit court decisions also suggest that an untenured teacher who, through her classroom speech, unknowingly violates a school restriction of which she lacked notice and loses her position on that basis may well have an actionable constitutional claim under principles of vagueness and substantive due process. See, e.g., Bradley v. Pittsburgh Bd. of Educ., 910 F.2d 1172, 1177 (3d Cir. 1990) (stating that although the plaintiff teacher, in arguing that the ban on a particular classroom technique was vague and overbroad, had "couche[d] her claim in First Amendment terms, her argument is basically a due process one. We have stated in a different context that a rule that forbids the doing of an act in terms so vague that people of common intelligence must guess as to its meaning and differ as to its application violates due process."); Ward v. Hickey, 996 F.2d 448, 453 (1st Cir. 1993) (holding that even if "a school may prohibit a teacher's statements before she makes them, ... it is not entitled to retaliate against speech that it never prohibited"); Conward v. The Cambridge School Committee, 171 F.3d 12, 23 (1st Cir. 1999) (reiterating that teachers must be given "appropriate notice of what sorts of expressive conduct are out of bounds"). Additionally, in certain circumstances untenured teachers are entitled to procedural due process (i.e., notice and a hearing) before they can be terminated.
} 
peg of teacher classroom speech into the round hole of Hazelwood ends up distorting

Hazelwood itself, undermining Hazelwood's utility in the student speech context for

which it was actually designed.

Hazelwood should similarly be inapplicable to restrictions on the speech of outside entities in school-sponsored settings. As described above, Hazelwood's analysis

proceeds in two parts: Section II.A summarizes the Court's general public forum doctrine, with repeated reference to Perry and Cornelius; and Section II.B fleshes out what "reasonableness" means in the specific context of school-sponsored student speech (implying, in the process, the permissibility of certain viewpoint-based restrictions, as discussed above and as discussed further below). When the speaker is an outside entity rather than a student, there is no need to proceed to Section II.B, which was formulated specifically for student speech. Rather, general public forum doctrine should be applied.

The courts that have applied Hazelwood to outside entity speech have, in practice, actually ended up doing this. But rather than doing so by deeming Hazelwood inapplicable outside of the student context, as I urge, they have done so by interpreting

See Perry v. Sindermann, 408 U.S. 593, 599-603 (1972). See also Buss, Academic Freedom, supra note 9 , at 262-274 (arguing that outside of the First Amendment, notions of implied contractual terms, procedural due process, and substantive due process all provide protection for teachers' classroom speech, particularly where they have not received adequate notice that the speech in question was prohibited). Karen Daly, as discussed above, also argues that the presence or absence of notice should determine the level of protection accorded teachers' classroom speech.

Additionally, a school district obviously remains free to provide its teachers with additional protection for their classroom speech. See, e.g., N. La. Board Policy "Next Wave of Attack by AntiEvolution Forces," THE TIMES-PICAYUNE, Dec. 14, 2006 (describing one northern Louisiana parish's new policy regarding the teaching of science, which stated that the district "understands that the teaching of some scientific subjects such as biological evolution, the chemical origins of life, global warming and human cloning, can cause controversy and that some teachers may be unsure of the district's expectations concerning how they should present information on such subjects" and that "teachers shall be permitted to help students understand, analyze, critique and review in an objective manner the scientific strengths and weaknesses of existing scientific theories pertinent to the course being taught." Assuming arguendo that this policy would pass muster under the Establishment Clause, it would arguably provide additional security to teachers (such as the plaintiff teacher in Webster v. New Lenox School Dist. No. 122, 917 F.2d 1004 (7th Cir. 1990)) who chose to discuss creationism in the classroom. 
Hazelwood in a way that makes it functionally indistinguishable from basic public forum analysis. In Searcey, for example, the Eleventh Circuit concluded that the Career Day at issue was a nonpublic forum, that speech restrictions as to the speakers must therefore be reasonable and viewpoint neutral, and that certain restrictions passed that test while others did not. ${ }^{247}$ The only role that Hazelwood played in the discussion, therefore, was in the court's rejection of the school district's argument that Hazelwood had eliminated the viewpoint neutrality requirement. ${ }^{248}$ Indeed, the Searcey court specifically stated that Hazelwood "does not alter the test for reasonableness in a nonpublic forum such as a school but rather provides the context in which the reasonableness of regulations should be considered." ${ }^{249}$ The Searcey court would thus have reached the identical result had it held Hazelwood altogether inapplicable.

Similarly, in Planned Parenthood, the Ninth Circuit ruled the yearbook in question a nonpublic forum, interpreted Hazelwood as maintaining the viewpoint neutrality requirement, and then assessed the speech restriction to determine whether it had been reasonable and viewpoint neutral. ${ }^{250}$ Again, the result would have been identical had the Ninth Circuit simply deemed Hazelwood inapplicable to the speech of outside entities. Indeed, once Hazelwood is interpreted as containing a viewpoint neutrality requirement, it becomes identical to the general approach to a nonpublic forum. The viewpoint neutrality requirement is the same, and Hazelwood"s "reasonable relation

\footnotetext{
${ }^{247}$ Searcey, 888 F.2d at 1318-26.

${ }^{248}$ Id. at 1319 \& n. $7 ; 1324-25$.

${ }^{249}$ Id. at 1319.

${ }^{250}$ Planned Parenthood, 941 F.2d at 829.
} 
to a legitimate pedagogical purpose" standard simply becomes one way of phrasing the general reasonableness requirement for nonpublic fora. ${ }^{251}$

General public forum doctrine also provides schools with the flexibility that they need to restrict inappropriate outside entity speech in school-sponsored settings. As an initial matter, schools are not required to open their doors to outside entities in the first place. While the presence of students and teachers in schools is a given, the presence of outside entities is not. Once a school decides to open its doors to outside entities whether, for example, by making its facilities generally available after school, holding a career forum, selling ads in its yearbook, or providing outside entities with access to its distribution systems - it can set the terms for that access. It can create a limited public forum, in which all individuals who wish to speak about a topic that falls within the forum's boundaries are presumptively entitled to access. Or it can create a nonpublic forum in which each speaker must individually obtain permission before participating, in which case restrictions as to particular speakers will be permissible as long as they are reasonable and viewpoint-neutral. Alternatively, if the school is simply bringing in a particular outside speaker to serve as its own agent in conveying a particular message to students (for example, an outside health educator to speak about the dangers of drug use or unsafe sex), then no forum at all has been created, and no other outside entities will be able to claim a First Amendment right of access. ${ }^{252}$

\footnotetext{
${ }^{251}$ See Fleming v. Jefferson Cty. Sch. Dist., 298 F.3d 918, 926 (10th Cir. 2002) (similarly observing, en route to its conclusion that Hazelwood must not require viewpoint neutrality, that "if Hazelwood required viewpoint neutrality, then it would essentially provide the same analysis as under a traditional nonpublic forum case: the restriction must be reasonable in light of its purpose (a legitimate pedagogical concern) and must be viewpoint neutral.").

${ }^{252}$ See, e.g., Make the Road by Walking, Inc. v. Turner, 378 F.3d 133, 151 (2d Cir. 2004) (stating that "[o]nly where the government allows private parties to express their personal views in a nonpublic forum is it required to avoid viewpoint discrimination" and that if a government entity or its contractual agents are
} 
Applying Hazelwood to outside entity speech, and stretching it to mirror general public forum doctrine in the process, is therefore both unnecessary and unwise. It is unnecessary because general public forum doctrine can do the job on its own, and Hazelwood should not be interpreted as supplanting it outside of the student speech context. And it is unwise because, as Downs and particularly Bannon illustrate, it leads to precedents that end up complicating subsequent applications of Hazelwood to student speech.

Finally, as to textbook and curricular selections, the Third, Fifth, and Seventh Circuits have persuasively explained, in Edwards, Chiras, and Mayer respectively, why these reflect school district-level decisions and thus amount to pure government speech. As such, here tooHazelwood is inapplicable. Hazelwood's reach should therefore be narrowed back to the context in which it first arose: school-sponsored student speech.

\section{My Proposal: A Sliding-Scale Approach for Student Speech}

The extension of Hazelwood to a broad range of speech contexts has not only unnecessarily complicated the viewpoint discrimination analysis. It has also rendered it increasingly abstract, with courts largely treating it as a simple "yes or no" question. Returning to Hazelwood's core as a student speech case, in turn, helps to sharpen the analysis of this issue.

It seems relatively clear that Hazelwood contemplated the permissibility of viewpoint-based restrictions as to school-sponsored student speech in at least some circumstances. As described above, the Hazelwood Court stated that public schools must

the only speakers on government property, then "there is no actionable viewpoint discrimination, because there is no discrimination "). 
"retain the authority to refuse to sponsor student speech that might reasonably be perceived to advocate drug or alcohol use, irresponsible sex, or conduct otherwise inconsistent with the shared values of a civilized order, ${ }^{, 253}$ and that schools may also dissociate themselves from speech that is "biased or prejudiced."254 The Court went on to argue that if Tinker - as opposed to its newly-announced standard - applied to school newspapers, schools would be faced with including in their newspapers "all student expression that does not threaten 'material disruption of classwork or violation of 'rights that are protected by law,' regardless of how sexually explicit, racially intemperate, or personally insulting that expression otherwise might be. ${ }^{.255}$ And it predicted that in order to prevent that from occurring, many schools would go so far as to dissolve their student newspapers altogether. ${ }^{256}$

These statements strongly point toward the permissibility of viewpoint-based restrictions in some circumstances. After all, if Hazelwood does not allow viewpointbased restrictions, it is difficult to see how it achieves the Hazelwood Court's expressed goal of providing schools with additional discretion - beyond what they already possess under Tinker - to censor, in school-sponsored settings, student speech that expresses, e.g., pro-drug, pro-drinking, or "racially intemperate" views. Hazelwood's omission of any viewpoint neutrality requirement further points in this direction. Indeed, Susannah Barton Tobin - while opposing viewpoint-based restrictions and urging the Court to revisit this issue - concedes that "evidence indicates that the 1988 [Hazelwood] Court might have intended to abandon the viewpoint neutrality requirement for school

${ }^{253}$ Hazelwood, 484 U.S. at 272.

${ }^{254} \mathrm{Id}$. at 271.

${ }^{255} I d$. at 276 \& n.9.

${ }^{256} \mathrm{Id}$. 
speech." ${ }^{257}$ Interestingly, Tobin reports that when she interviewed one of the Hazelwood students' attorneys about the case, he described himself as "somewhat astonished to learn that some courts have construed the case as prohibiting, or at least not authorizing, censorship based on the speaker's views," reflecting that "I always thought that it quite clearly did sanction viewpoint discrimination."258

But concluding that Hazelwood permits viewpoint discrimination as to some school-sponsored student speech should only be the start of the analysis. The more challenging issue - and the one that remains relatively unexplored - is when such viewpoint-based restrictions should be allowed under Hazelwood. In other words, given the general suspicion of viewpoint-based restrictions, when will a school's viewpointbased restriction sufficiently relate to legitimate pedagogical concerns? This question can best be answered through a sliding-scale approach that incorporates the two core aspects of Hazelwood: (1) the initial trigger for Hazelwood's applicability, i.e., the occurrence of the speech in a school-sponsored activity that "students, parents, and members of the public might reasonably perceive to bear the imprimatur of the school"; and (2) the ultimate standard once Hazelwood applies, i.e., that the speech restriction be "reasonably related to legitimate pedagogical concerns." As described below, the stronger the perception of school imprimatur over the student speech at issue, the more latitude the school should receive to restrict it by means of viewpoint-based restrictions. $^{259}$

257 Tobin, supra note 9 , at 219.

${ }^{258} I d$. at 228 .

${ }^{259}$ Cf. Jordan, supra note 9, at 1573-74 (arguing that "the range of pedagogical concerns considered 'legitimate' to sustain a restriction" should vary depending on whether the restriction is viewpoint-based, and that the "avoidance of controversy" should not qualify as a legitimate pedagogical concern for purposes of viewpoint-based restrictions). My proposal, rather than taking the question of whether a restriction is viewpoint-based as its starting point, instead begins earlier: with an assessment of the school-sponsored 
The trigger for Hazelwood's applicability is a relatively low one. Hazelwood encompasses students' speech in the classroom, ${ }^{260}$ in their written assignments, ${ }^{261}$ in school publications, ${ }^{262}$ in school assemblies, ${ }^{263}$ in school productions, ${ }^{264}$ in artwork that temporarily or permanently decorates the school halls, ${ }^{265}$ and in any other activity that is supervised by faculty members, designed to impart knowledge or skills to student participants, and could be perceived by others as bearing the school's imprimatur. Given this relatively wide range, not all Hazelwood-qualifying student speech is going to be equally suggestive of school imprimatur. Generally speaking, the perception of imprimatur will be at its highest in two situations: where the student speech is changing the permanent physical appearance of the school itself; or where the student speech is substantively changing the nature of other students' classroom experience. In such instances, the student expression comes relatively close to functioning as the school's own speech, particularly in terms of its practical effect. Here, school officials should receive broad latitude to restrict student speech, even if their restrictions are viewpoint-

context in which the restriction is occurring, in terms of how strong the perception of school imprimatur is likely to be. That initial assessment, in turn, determines the applicable level of scrutiny for viewpointbased restrictions.

${ }^{260}$ See, e.g., C.H. v. Oliva, 195 F.3d 167 (3d Cir. 1999) (applying Hazelwood to school restrictions on student's ability to read Bible story to class, aff'd in part by an equally divided court and vacated and remanded in part, 226 F.3d 198, 202-203 (3d Cir. 2000) (en banc); DeNooyer v. Livonia Public Schools, 799 F. Supp. 744 (E.D. Mich. 1992) (applying Hazelwood to school restrictions on student's show-and-tell performance), aff'd, 1993 U.S. App. 20606 (6th Cir. 1993) (summary order).

${ }^{261}$ See, e.g., Duran v. Nitsche, 780 F. Supp. 1048 (E.D. Pa. 1991) (applying Hazelwood to school restrictions on student's choice of paper topic).

${ }^{262}$ See, e.g., Hazelwood; Paye v. Gibraltar Sch. Dist., 1991 U.S. Dist. LEXIS 16480 (E.D. Mich. 1991) (applying Hazelwood to school restrictions on contents of student literary magazine).

${ }_{263}$ See, e.g., Poling v. Murphy, 872 F..2d 757 (6th Cir. 1989) (applying Hazelwood to school disciplinary action against student for the speech he delivered during a mandatory school assembly).

${ }^{264}$ See, e.g., McCann v. Fort Zumwalt Sch. Dist., 50 Supp. 2d. 918 (E.D. Mo. 1999) (applying Hazelwood to school restrictions on high school marching band's choice of songs).

${ }^{265}$ See, e.g., Peck v. Baldwinsville, 426 F.3d 617 (2d Cir. 2005) (applying Hazelwood to student artwork that was to be temporarily displayed during environmental assembly); Fleming v. Jefferson Cty. Sch. Dist., 298 F.3d 918 (10th Cir. 2002) (applying Hazelwood to tiles that were to be affixed to school walls);

Bannon v. Sch. Dist. of Palm Beach Cty., 387 F.3d 1208 (11th Cir. 2004) (applying Hazelwood to studentcreated mural that were to remain in school hallways for up to four years). 
related. By contrast, where the speech is clearly attributable to a particular student and is altering neither the school's permanent physical appearance nor other students' classroom experience, the perception that the school affirmatively approves of the student speech as opposed to simply permitting its dissemination - is likely to be lower. This latter category will typically include student speech that is delivered at a school assembly, printed in a school publication, or submitted in response to a particular class assignment. Here, Hazelwood's standard should be applied more stringently, with school speech restrictions that involve viewpoint discrimination being subjected to examination more akin to intermediate scrutiny than to rational basis review.

This distinction is nicely illustrated by the Third Circuit case of C.H. v. Oliva, ${ }^{266}$ which involved two instances of school-sponsored student speech falling on different places along the "imprimatur spectrum." The first instance occurred when the plaintiff child was in kindergarten. His kindergarten teacher, in connection with Thanksgiving, asked the students in the class to make posters depicting what they were thankful for. ${ }^{267}$ The plaintiff created a poster indicating that he was thankful for Jesus. ${ }^{268}$ His poster was hung in the hallway along with the other posters produced by students in the plaintiff's class, but it was subsequently removed and then placed in a less prominent location. ${ }^{269}$ The second instance occurred approximately eighteen months later, when, as part of the reading instructional program, the plaintiff's first-grade teacher invited students to bring in a book from home and read one of their favorite stories to the entire class. ${ }^{270}$ The

\footnotetext{
${ }^{266}$ C.H. v. Oliva, 195 F.3d 167 (3d Cir. 1999), aff'd in part by an equally divided court and vacated and remanded in part, 226 F.3d 198, 202-203 (3d Cir. 2000) (en banc).

${ }^{267} 195$ F.3d at 168.

${ }^{268} \mathrm{Id}$.

${ }^{269} \mathrm{Id}$. at $168-69$.

${ }^{270} \mathrm{Id}$. at 169.
} 
plaintiff brought in "The Beginner's Bible" and sought to read a Bible story to his classmates. ${ }^{271}$ The teacher did not allow him to read the story to his classmates because of its religious content, and instead had him read it to her in private. ${ }^{272}$

The first-grade Bible story incident is a good example of school-sponsored student speech that is likely to produce a strong perception of school imprimatur. The classroom is at the center of a school's pedagogical mission, and schools should have significant discretion over what is taught there. This was not a situation where the student simply would have been expressing his own views in response to a question or class assignment. Rather, the student, in reading a Bible story to his classmates as part of a classroom lesson, would have been changing the very nature of that lesson and affecting his fellow students' classroom experience. As the Third Circuit stated in its initial opinion on the case:

[T] he classroom setting involve[s] a religiously heterogeneous and captive audience. It is not unreasonable to expect that parents of non-Christian children would resent exposure of their six-year-old children to a reading from the Bible. Nor is it unreasonable to expect that some parents of Christian first graders would regard a compelled classroom exposure to material from the Bible as an infringement of their parental right to guide the religious development of their children at this stage. Moreover, it is not unreasonable to expect that any resentment engendered by [the plaintiff's] reading would have a significant adverse impact on the important relationship between the parents, the teacher, and their school. ${ }^{273}$

Indeed, given that other students would have been compelled to listen to the Bible story, it is even possible that had the school permitted the Bible reading to go forward, it would have faced claims of an Establishment Clause violation by other parents.

\footnotetext{
${ }^{271} I d$.

${ }^{272} \mathrm{Id}$.

${ }^{273} \mathrm{Id}$. at 175 .
} 
But a school should not have to show that speech will cause an Establishment Clause violation in order to justify its decision to exclude it from a classroom lesson. When it comes to the substance of classroom lessons, which are at the core of a school's educational mission, school officials should retain broad discretion to restrict student speech for any legitimate pedagogical purpose - including the avoidance of potential disruption or discomfort by other students and their parents - even if doing so entails a viewpoint-based restriction. Of course, schools should not have entirely free rein to restrict student speech in the classroom setting. A restriction that is truly unrelated to any legitimate pedagogical purpose (for example, a classroom election-day activity in which students can only speak in favor of candidates from one party) should be held unconstitutional. Provided that the school can articulate a genuine pedagogical justification for its restriction, however, the restriction should pass constitutional scrutiny regardless of whether it is viewpoint-related.

A similar high-imprimatur situation was presented in Walz v. Egg Harbor Township Board of Education, ${ }^{274}$ in which a first-grader sought to pass out candy canes bearing religious messages (which explained that the candy cane represented Jesus, "who came to earth as our Savior") to his fellow students during an in-class seasonal holiday party. ${ }^{275}$ The pedagogical purpose of the party, according to the school, was "to teach social skills and respect for others in a festive setting."276 The school, having prohibited students from bringing in any gifts with commercial, political, or religious messages, did not permit the student to distribute the candy canes at the party, although it did allow him

\footnotetext{
274342 F.3d 271 (3d Cir. 2003).

${ }^{275} I d$. at $273-75$. The student had also sought to do so the previous year, while in kindergarten. Id.

${ }^{276} \mathrm{Id}$. at 279.
} 
to do so at recess and after school. ${ }^{277}$ The court upheld the constitutionality of the school's actions, explaining that "[the student] was not attempting exercise a right to personal religious observance in response to a class assignment or activity. His mother's stated purpose was to promote a religious message through the channel of a benign classroom activity." 278 Again, had the student been permitted to engage in the speech in question, the very substance of the classroom activity would have changed. The school's determination that it wanted to maintain the secular nature of this activity warranted great deference.

Other cases falling at the high end of the imprimatur spectrum include Fleming $v$. Jefferson County School District ${ }^{279}$ and Bannon v. School District of Palm Beach County, ${ }^{280}$ in which the speech at issue would have changed the permanent physical appearance of the school. In Fleming, as discussed above, ${ }^{281}$ the tiles in question were to be installed throughout the schools of Columbine High School, becoming a permanent part of the school's interior. Similarly, in Bannon, the religiously-themed murals were to remain in the school's exterior and interior hallways throughout the duration of the school's long-term remodeling project, which was to last up to four years. ${ }^{282}$ In both cases, therefore, the speech in question was going to transform the appearance of the school itself in a relatively permanent fashion, lasting long after the creator of that speech was gone. The Fleming Court itself emphasized this aspect, stating that "expressive activities that the school allows to be integrated permanently into the school environment

\footnotetext{
${ }^{277} \mathrm{Id}$. at 274 .

${ }^{278} I d$. at 280.

279298 F.3d 918 (10th Cir. 2002).

${ }^{280} 387$ F.3d 1208 (11th Cir. 2004).

${ }^{281}$ See supra text accompanying notes 189-91.

${ }^{282}$ Bannon, 387 F.3d at 1210.
} 
and that students pass by during the school day come much closer to reasonably bearing the imprimatur of the school."283 The same is essentially true of Bannon. In these cases, therefore, the schools were properly granted broad discretion to restrict the speech at issue, even though some of their restrictions were viewpoint-based. Like classroom lessons, the permanent physical appearance of the school is almost inseparable from the school itself. A reasonable observer is likely to perceive speech permanently etched on school walls as the school's own, or, at the very least, as strongly indicative of the school's own views.

The kindergarten incident in Oliva, by contrast, provides a good example of student speech that, despite occurring in a school-sponsored context, was not strongly suggestive of school imprimatur. The student's poster was going to be temporarily hung in a school hallway alongside numerous other posters responding to the same Thanksgiving assignment. The poster was clearly attributable to one particular student, was presumably going to be removed relatively soon after the Thanksgiving holiday, and was not affecting the substance of any classroom lesson or activity. In fact, then-Judge Alito - in dissenting from the Third Circuit's en banc dismissal of the plaintiff's claim as to his poster - argued that the poster should not even be considered Hazelwoodqualifying speech, asserting that "[t]hings that students express in class or in assignments when called upon to express their own views do not bear the imprimatur of the school and do not represent the school's own speech" and that "reasonable students, parents, and members of the public would not have perceived [the plaintiff's] poster as bearing the

\footnotetext{
${ }^{283}$ Fleming, 298 F.3d at 925. See also Tobin, supra note 9, at 261 (writing, in regard to Fleming, that "[u]nlike a newspaper article, a speech, or even a temporary display of artwork, the tiles were intended to become part of the fabric of the school building, and as such, were not easily distanced from the school's own beliefs").
} 
imprimatur of the school or as an expression of the school's own viewpoint."284 This is an aggressive interpretation of Hazelwood, which expressly stated that it covered all activities that were part of the school curriculum. But Judge Alito's larger point - that speech contained in one student's response to a school assignment is unlikely to yield a strong perception of school imprimatur - is well-taken.

A strikingly similar situation arose in Peckv. Baldwinsville Central School District, ${ }^{285}$ in which a kindergartner, in response to an assignment to create a poster illustrating ways to help the environment, drew a poster that included depictions of children recycling, trees, grass, and a "robed, praying figure" intended to be Jesus. ${ }^{286}$ His teacher, when hanging all of the students' posters for an environmental assembly, folded the plaintiff student's poster in half so that the portion depicting Jesus was concealed. ${ }^{287}$ The Second Circuit held that the student's resulting First Amendment claim could go forward, ruling (as noted above ${ }^{288}$ ) that Hazelwood generally prohibited viewpoint discrimination. ${ }^{289}$ Here, too, the perception of school imprimatur in regard to the student's poster was low, given that the poster was hung alongside numerous other posters for a limited duration and was clearly attributable to one particular student. It is unlikely that any observer, viewing the student's poster in the context of the posters

\footnotetext{
${ }^{284}$ Oliva, 226 F.3d at 214 (Alito, J., dissenting). The en banc majority, as noted above, had dismissed the claim on grounds that the complaint lacked sufficient detail, and thus did not reach the core Hazelwood issue. The lower court had held that the decision to temporarily remove and subsequently relocate poster satisfied Hazelwood, stating that "[g]iven the sensitivity of the issues raised by student religious expression, coupled with the notable immaturity of the students involved and the relatively public display of the posters in the school hallway, the school's temporary removal of the poster does not violate the First Amendment rights of the student artist." Oliva, 195 F.3d at 175.

${ }^{285} 426$ F.3d 617.

${ }^{286} I d$. at 622 .

${ }^{287} \mathrm{Id}$.

${ }^{288}$ See supra text accompanying notes $184-85$.

${ }^{289} I d$. at $631-33$.
} 
created by the entire class, would have believed that the school itself agreed with or had communicated the view that Jesus was a way to save the environment.

Student speech at assemblies or publications will also typically yield a relatively weak perception of school imprimatur. In Poling $v$. Murphy, ${ }^{290}$ for instance, the plaintiff student's campaign speech for student council president - in which he stated: "[t]he administration plays tricks with your mind and they hope you won't notice. For example, why does [the assistant principal] stutter when he is on the intercom? He doesn't have a speech impediment. If you want to break the iron grip of this school, vote for me for president. ${ }^{, 291}$ - was one of numerous speeches delivered by various student candidates during a school assembly. There is no question that the assembly, which was overseen by a faculty advisor to the student council and which all students were required to attend, ${ }^{292}$ fell within Hazelwood's broad umbrella. But it is less likely that the student body actually perceived school officials as necessarily agreeing with all of the views espoused by the different candidates. Rather, any perception of school imprimatur was likely limited to an impression that the school had permitted its students to make these speeches as part of the self-government opportunities offered to them, and that school officials did not deem the speeches so inappropriate as to warrant exclusion. Studentauthored editorials and articles in school newspapers, magazines, yearbooks, and other publications are similarly unlikely to yield a particularly strong impression of school imprimatur. The very existence of the student author's by-line implies some level of distinction between the school's own views and the views of that student.

\footnotetext{
${ }^{290} 872$ F.2d 757 (6th Cir. 1989).

${ }^{291}$ Id. at 759 .

292 Id. at 758-59.
} 
This is not to say that schools should not have considerable power to restrict student speech in school-sponsored contexts that fall on the low end of the "imprimatur spectrum," i.e., student speech that just satisfies the Hazelwood threshold. Hazelwood, itself a school newspaper case, clearly establishes this authority. It does, however, mean that when school restrictions as to such speech are viewpoint-based, those restrictions should at least be subject to some real scrutiny, given the general suspicion of viewpoint discrimination and the failure of Hazelwood to speak explicitly to this issue. Indeed, although Hazelwood can be seen as generally providing for deferential "rational basis" review, ${ }^{293}$ this is the sub-category of Hazelwood cases in which review more akin to intermediate scrutiny is appropriate. Rather than being required to show merely a reasonable relationship to a legitimate pedagogical concern, a school imposing a viewpoint-based restriction as to student speech in a context yielding only a weak perception of school imprimatur should have to show that the restriction is substantially related to an important pedagogical purpose - that is, that there is an exceedingly persuasive justification for the restriction. $^{294}$

This sliding-scale approach, whereby the level of scrutiny of viewpoint-based restrictions would be inversely related to the level of school imprimatur, would have two speech-protective results. First, in low-imprimatur settings triggering intermediate scrutiny, a school would not be able to impose a viewpoint-based restriction without connecting it to an important pedagogical concern. Not all of the pedagogical concerns

\footnotetext{
${ }^{293}$ See, e.g., Stuller, supra note 9, at 322 (referring to Hazelwood's standard as "rational basis review in the educational setting").

${ }^{294}$ Cf. Craig v. Boren, 429 U.S. 190, 197 (1976) (establishing an intermediate level of scrutiny (in the context of gender-based classifications), under which classifications are permissible if they are substantially related to an important governmental purpose); U.S. v. Virginia, 518 U.S. 515, 533 (1996) (describing this standard as requiring an "exceedingly persuasive" justification).
} 
that Hazelwood identified as "legitimate" would necessarily rise to this level, particularly given that this more stringent standard would only apply to student speech cases at the low end of the imprimatur spectrum. For example, Hazelwood listed, as two of its legitimate pedagogical concerns, "assur[ing] that .... the views of the individual speaker are not erroneously attributed to the school" and preserving a school's "authority to refuse to sponsor student speech that might reasonably be perceived to ... associate the school with any position other than neutrality on matters of political controversy. ${ }^{, 295}$ But once the speech in question has already been found to yield only a weak perception of school sponsorship, it is unlikely that this type of concern will be sufficiently important to justify a viewpoint-based restriction. Similarly, if the school's proffered pedagogical interest in imposing the viewpoint-based restriction is the avoidance of potential disruption, the school should be required to show a significant likelihood that disruption will result from dissemination of the student's speech in order to establish an important pedagogical concern.

Second, in such low-imprimatur settings, the school would also have to demonstrate a substantial - not just a "reasonable" - relationship between the viewpointbased nature of the restriction and the important pedagogical concern. This differs from Hazelwood's suggestion that generally, the particular method by which the school official restricts the student speech need not be closely scrutinized. That message was communicated by the Hazelwood Court's apparent lack of concern over the principal's harsh method of censoring the two articles in question - i.e., pulling two entire pages (which also included other articles) out of the newspaper, rather than deleting only the two articles in question or giving the student authors the opportunity to make changes.

\footnotetext{
${ }^{295}$ Hazelwood, 484 U.S. at 272.
} 
Acknowledging that the principal had not looked into whether these more limited alternative options were feasible, the Court simply noted that the principal's actions were "reasonable under the circumstances as he understood them."296 Even assuming arguendo that those actions were reasonable for purposes of a rational basis review, it is unlikely that they would satisfy intermediate scrutiny, given that the principal's pedagogical concerns could have been readily satisfied by the alternative means described above. Only where the important pedagogical concern cannot be effectively achieved through a viewpoint-neutral approach should the school officials be deemed as having proffered an exceedingly persuasive justification for their viewpoint-based restriction. Thus, a viewpoint-based restriction motivated solely by the school's desire to avoid being associated with a controversial position would presumably fail not only because this is unlikely to be an important pedagogical concern in the first place (given the low perception of school imprimatur), but also because other methods - such as prominent disclaimers - could achieve the same goal without suppressing the student speaker's views. More broadly, before imposing a viewpoint-based restriction on a student's speech, school officials would need to communicate with the student to determine whether there were any non-viewpoint-based approaches through which the school's concerns about the student expression could be alleviated.

The notion of using a sliding-scale approach to assess restrictions on schoolsponsored student speech accords with Supreme Court precedent on both the school and speech fronts. Indeed, in several other contexts involving public school students' constitutional rights, the Supreme Court has already turned to sliding-scale frameworks as the best way of balancing students' rights against schools' educational and safety

${ }^{296} I d$. at 276. 
needs. With regard to students' Fourth Amendment rights in the context of random drug testing, for example, the Court held in Vernonia School District $47 J$ v. Acton ${ }^{297}$ that the constitutionality of such testing depends upon a fact-specific weighing of the nature and the immediacy of the school's interest in conducting the testing against the nature of the students' privacy interest and the character of the intrusion. ${ }^{298}$ Similarly, as to students' Fourteenth Amendment procedural due process rights in the context of school discipline, the Court indicated in Goss v. Lopez ${ }^{299}$ that the level of process that is due depends on the extent of the discipline imposed, holding that suspensions of ten days or less require some type of "notice and informal hearing," while "longer suspensions and expulsions for the remainder of the school term, or permanently, may require more formal procedures. $" 300$

Meanwhile, on the speech front, the Pickering-Connick framework itself involves a sliding-scale analysis at the second prong of the analysis. As described above, once a court has concluded that the First Amendment threshold is satisfied - i.e., that the plaintiff employee was speaking about a matter of public concern in his capacity as a citizen - it then proceeds to a balancing test in which the employer's interest in regulating the speech is weighed against the employee's First Amendment interest in uttering it. The Connick Court was explicit about the sliding-scale nature of this approach, stating

\footnotetext{
${ }^{297} 515$ U.S. 646 (1995).

${ }^{298}$ Id. at 654-665. Pursuant to this framework, the Vernonia Court upheld the school district's policy of requiring student athletes to submit to random urinalysis drug testing, explaining that student athletes had reduced expectations of privacy, that the nature of the intrusion was relatively minimal given the way in which the samples were collected as well as the fact that results were not turned over to law enforcement, and that the school district's interest in combating its drug use problem was great. $I d$. The Supreme Court subsequently upheld a similar policy involving random urinalysis drug testing of student participants in extracurricular activities. Bd. of Educ. v. Earls, 536 U.S. 822 (2002). Again, the Court emphasized the privacy-shielding method of urine collection as well as the fact that failing results were not turned over to law enforcement, thus implying that greater levels of intrusion would require correspondingly greater levels of justification. Id. at 832-33.

299419 U.S. 565 (1975)

${ }^{300} \mathrm{Id}$. at 584 .
} 
that "a stronger showing may be necessary if the employee's speech more substantially involved matters of public concern."301 Acknowledging that "such particularized balancing is difficult," the Court emphasized that "the court must reach the most appropriate possible balance of the competing interests., ${ }^{302}$

Just as the Supreme Court has recognized the appropriateness of sliding-scale approaches as to other constitutional issues involving both schools and speech, so too does this article's proposed sliding-scale approach provide a helpful way of analyzing the difficult questions raised by viewpoint-based restrictions of student speech in schoolsponsored settings. Indeed, returning to some of the cases discussed above usefully illustrates how this article's proposed approach would play out in practice.

The key points of departure between the actual resolution of these cases and the proposed approach's resolution of these cases can be seen in Oliva, Peck, and Poling. In Oliva, the initial three-judge panel of the Third Circuit applied the same level of scrutiny to both the kindergarten Thanksgiving poster depicting Jesus and the first-grade Bible story incident, and upheld the constitutionality of both restrictions on that basis. ${ }^{303} \mathrm{My}$ sliding-scale approach, by contrast, would require viewpoint-based restrictions as to the Thanksgiving poster to satisfy intermediate scrutiny, given the low perception of imprimatur there. It is unlikely that they could have passed this test. None of the "legitimate pedagogical concerns" identified by the Oliva panel with regard to removal and relocation of the poster - "the sensitivity of the issues raised by student religious expression, coupled with the notable immaturity of the students involved and the

\footnotetext{
${ }^{301}$ Connick, 461 U.S. at 152.

${ }^{302} I d$. at 150 .

${ }^{303}$ Oliva, 195 F.3d at $174-76$.
} 
relatively public display of the posters in the school hallway" ${ }^{304}$ - is particularly strong. No evidence was cited that the poster interfered with any classroom lessons, caused any (let alone significant) disruption in the hallways, or placed the school in violation of the Establishment Clause. Thus, this article's proposed approach would yield the same result as to the Bible story, but a different result as to the Thanksgiving poster.

With Peck and Poling, meanwhile, my proposed approach would lead to the same ultimate result, but on somewhat different grounds. In Peck, as noted above, the Second Circuit took the opportunity to rule that Hazelwood generally prohibited viewpoint-based restrictions. Under this article's approach, by contrast, the concealment of the Jesus figure on the student's poster would be unconstitutional not because viewpoint-based discrimination is always prohibited by Hazelwood, but because the context there was insufficiently suggestive of school imprimatur to warrant the speech restriction.

Finally, as to Poling, the school officials' discipline of the student would be entirely permissible under my proposed approach. That is because the discipline, at least as the school officials explained it, stemmed not from opposition to the views expressed by the student, but rather from the conclusion that the student's mockery of the assistant principal's stuttering had been rude and in poor taste. ${ }^{305}$ Given that the speech restriction at issue was not viewpoint-based, my proposed approach would require it only to be reasonably related to legitimate pedagogical concerns. By contrast, had the student simply criticized the administration's "iron grip" on the school without using personally derogatory language, and had the school still punished him, then such discipline would clearly have been based on the substance of the student's anti-administration viewpoint.

\footnotetext{
${ }^{304}$ Id. at 175.

${ }^{305}$ Poling, 872 F.2d at 759-60.
} 
Under my proposed approach, such a viewpoint-based restriction would be subject to heightened scrutiny (due to the low-imprimatur setting), and would not likely pass constitutional muster, given the lack of any apparent important pedagogical purpose.

\section{Conclusion}

In arguing that Hazelwood's reach has been significantly over-extended, I asserted above that a "one-size-fits-all" approach to Hazelwood is destined for failure. Hazelwood was designed specifically to evaluate restrictions on school-sponsored student speech, and courts should limit its application to that context, applying general public forum doctrine to outside entities' speech in school-sponsored settings and Pickering to teachers' classroom speech. The confusion and dissension over whether Hazelwood permits viewpoint-based restrictions has been an unfortunate byproduct of its overextension.

But even within Hazelwood's core of student speech, a one-size-fits-all approach to the viewpoint discrimination issue is not the best method. Hazelwood itself arose from the Supreme Court's recognition that context matters. Just as the existence of schoolsponsorship determines whether Tinker or Hazelwood applies in the first place, so too should the level of school sponsorship guide courts in determining exactly how Hazelwood should apply to each particular case. A more nuanced alignment between the perception of school imprimatur and the level of judicial scrutiny applied to viewpointbased restrictions, through the sliding-scale approach that I have proposed, will help fulfill the underlying rationale of the Tinker/Hazelwood regime and restore balance to school officials' treatment of student speech. 